Board of Governors of the Federal Reserve System

International Finance Discussion Papers

Number 724

April 2002

\title{
EQUITY PRICES, HOUSEHOLD WEALTH, AND CONSUMPTION GROWTH IN FOREIGN INDUSTRIAL COUNTRIES: WEALTH EFFECTS IN THE 1990S
}

\author{
Carol C. Bertaut
}

NOTE: International Finance Discussion Papers are preliminary materials circulated to stimulate discussion and critical comment. References in publications to International Finance Discussion Papers (other than an acknowledgment that the writer has access to unpublished material) should be cleared with the author or authors. Recent IFDPs are available on the Web at www.federalreserve.gov/pubs/ifdp/. 


\title{
EQUITY PRICES, HOUSEHOLD WEALTH, AND CONSUMPTION GROWTH IN FOREIGN INDUSTRIAL COUNTRIES: WEALTH EFFECTS IN THE 1990S
}

\author{
Carol C. Bertaut*
}

\begin{abstract}
Although most recent empirical research regarding the size and significance of the impact of changes in wealth on consumption has looked for such effects in the United States, equity prices in the 1990s rose considerably in most other industrial countries as well. This paper investigates the strength of the wealth effect across countries. Using a variety of methods, I find evidence of significant wealth effects in the United Kingdom and Canada of a size comparable to that in the United States, reflecting the importance of equities in aggregate household wealth in these countries. A significant wealth effect is also evident in Japan, but because household wealth has changed little on balance in Japan in recent years, this channel has been less important in explaining Japanese consumption growth in the second half of the 1990s. Despite a rapid appreciation in equity prices and an increase in equity ownership in the major continental European countries since 1995, equities remain a less important form of household wealth in most of these countries, and the consumption response to changes in wealth remains limited. However, in some smaller European countries where equity issuance is more common, the emerging evidence suggests that wealth effects may be more important.
\end{abstract}

Keywords: wealth effects, household wealth, consumption, stock ownership, housing

* The author is an economist in the Division of International Finance at the Federal Reserve Board of Governors. I thank many colleagues at the Federal Reserve Board and elsewhere for useful comments and discussions at many stages of this research, especially Hali Edison, Steve Kamin and Martha Starr-McCluer. Several research assistants provided considerable support at various stages, in particular Tim Troha and Alisa Wilson. The views expressed are solely the responsibility of the author, and should not be interpreted as reflecting those of the Board of Governors of the Federal Reserve System or any other person associated with the Federal Reserve System. 


\section{Introduction}

Traditional macroeconomic estimates suggest that, all else equal, personal consumption rises between 2 and 5 cents for every dollar of additional wealth in the United States. If that is the case, wealth gains stemming in large part from stock market appreciation from 1995 through early 2000 boosted U.S. consumer spending by about one percentage point per year in the late 1990s. From March 2000 through the end of 2001, however, U.S. equity prices declined over 25 percent, ${ }^{1}$ and the resulting decline in wealth has been a factor in explaining the recent slowdown in U.S. consumer spending.

Permanent or direct wealth effects operate through the appreciation or depreciation of household wealth, but changes in asset prices may also affect consumption in the short run by influencing consumer confidence and--in the case of real estate prices--through the availability and cost of consumer credit. Although most recent empirical research regarding the size and significance of the impact of changes in wealth on consumption has looked for such effects in the United States, equity prices through the 1990s also rose considerably in most other industrial countries, and more recently, have tumbled in those countries as well.

This paper investigates whether the strength of the wealth effect varies across countries, and if so, what factors may underlie the variation. Using a variety of methods, I find evidence of significant wealth effects in the United Kingdom and Canada of a size comparable to that in the United States, reflecting the importance of equities in aggregate household wealth in these countries. I also find evidence of a significant wealth effect in Japan, but because household wealth has changed little in Japan in recent years, this channel has contributed little to Japanese consumption growth in the second half of the 1990s. Despite a rapid appreciation in equity prices and an increase in equity ownership in continental European countries since 1995, however, equities remain a less important form of household wealth in most of these countries, and the evidence suggests that the consumption response to changes in wealth remains limited. However, as equity issuance increases in Europe and equities become a more important form of wealth, this channel is expected to become more important.

\footnotetext{
${ }^{1}$ As measured by the Wilshire 5000 index.
} 


\section{Estimates of the effects of asset prices or wealth on consumption for the United States}

The role of wealth effects on consumption has been most extensively studied for the United States, and the literature supporting this research has grown significantly in recent years. Commonly cited estimates of the marginal propensity to consume (mpc) out of wealth in the United States are typically in the range of 2 to 5 cents increased spending from a dollar increase in wealth. The wealth effect is frequently discussed in terms of stock market wealth, in large part because household wealth held in stocks either directly or indirectly through pensions, mutual funds, and 401-k retirement plans account for the lion's share of the increase in U.S. household assets over the past 10 years (see figures 2 and 4, discussed in more detail below). ${ }^{2}$ In his February 2000 Monetary Policy Report testimony, Federal Reserve Board of Governors Chairman Greenspan noted that "historical evidence suggests that perhaps three to four cents of every additional dollar of stock market wealth eventually is reflected in increased consumer purchases. The sharp rise in the amount of consumer outlays relative to disposable incomes in recent years, and the corresponding fall in the saving rate, has been consistent with this socalled wealth effect on household purchases."

Among estimates using time-series consumption, income, and wealth data, Reifschneider, Tetlow, and Williams (1999) note that in the Board of Governor's FRB-US Model, wealth effects from higher stock prices generate on average about $3 \frac{1}{2} 2$ cents additional consumer spending in the long run, ${ }^{3}$ and Davis and Palumbo (2001) find a wealth effect on U.S. consumption of between 3 and 6 cents for every dollar increase in stock market wealth. ${ }^{4}$ Other approaches include Poterba (2000), who reviews the recent literature on the U.S. wealth effect and presents a calibrated model showing that, depending on the after-tax return and the household's planning horizon, a permanent dollar increase in stock

\footnotetext{
${ }^{2}$ See Bertaut and Starr-McCluer (2000) for a general discussion of developments in U.S. household portfolios.

${ }^{3}$ Because model estimates a long-run elasticity, the implied mpc at wealth levels in the late 1990s is closer to 2 cents. See also Brayton and Tinsley (1996).

${ }^{4}$ A recent study by Ludvigson and Steindel (1999) also finds support for a relationship between consumption, wealth, and income in the United States with an estimate of the mpc out of stock market wealth of a comparable size to that in the FRB-US model: 0.04 when estimated over the period 1953-1997. However, they also find that their estimate of the mpc varies considerably depending on the estimation sample. Additionally, they do not find evidence that lagged changes in wealth affect future consumption.
} 
market wealth can plausibly raise current consumption between 3 and 10 cents. Dynan and Maki (2001) use micro data from the Consumer Expenditure Survey and find evidence of a direct impact of contemporaneous and lagged changes in stock prices on the spending of households that have stock market wealth; for households with moderate levels of such securities, consumption rises between 5 and 15 cents for every dollar increase in wealth. ${ }^{5}$ Using qualitative evidence from the University of Michigan's Survey of Consumers, Starr-McCluer (2000) finds support of a modest increase in spending from increases in stock market wealth.

Ongoing research shows that estimates of the strength of the wealth effect in the United States are sensitive to a number of factors, including the estimation sample, the measure of wealth used (total wealth including property wealth, net financial wealth only, stock market wealth), and the measure of consumption considered (including or excluding durables, including or excluding housing, real or nominal, including which deflator is used to generate real estimates). Nonetheless, the dramatic run-up in U.S. equity prices in the second half of the 1990s and the associated marked increase in U.S. household wealth and decline in the U.S. personal saving rate suggest that the wealth effect has been an important factor in explaining the robustness of U.S. consumption growth.

\section{Estimates of wealth effects in other countries}

Estimates of the strength of the wealth effect in other countries are limited, in large part because wealth data for other industrial countries often are not available for a sufficiently long time series for estimation. ${ }^{6}$ Many studies that compare the importance of changes in wealth or asset prices on consumption across foreign industrial countries either calibrate consumption responses to wealth based on estimates of the mpc for the United States, scaled by market capitalization relative to GDP or by the fraction of household wealth held in equities, or estimate reduced-form consumption growth equations

\footnotetext{
5 Dynan and Maki note that an implication of their results is that the mpc for wealthier households, which are excluded from their sample, may be smaller (in the range of 1 to 5 cents on the dollar).

${ }^{6}$ Studies that use the limited foreign household wealth data available typically look for effects in one or two countries. A recent study by Houziot et al (2000) finds an mpc for the United Kingdom of about 0.05, similar to their estimate for the United States. In its Annual Report 2000, the Bank for International Settlements reports estimates of consumption elasticities with respect to financial wealth that are consistent with estimated mpcs of 0.033 for the United States, 0.057 for the United Kingdom, and 0.022 for Australia.
} 
using stock price movements. ${ }^{7}$ In general, wealth effects-particularly those associated with stock market wealth-are thought to larger in the United States and possibly the United Kingdom than in other foreign industrial countries, because equities are an especially important form of both corporate finance and household wealth in both countries. For example, in the May 2000 World Economic Outlook, the IMF notes that

"the effects of stock prices on consumption appear to be the strongest in the United States, where most estimates point to an elasticity of consumption spending relative to net stock market wealth in the range of 0.03 to $0.07 \ldots$ in contrast, studies have not found any significant effect of stock prices on consumption in France and Italy, whereas for Canada, Germany, Japan, and the Netherlands, and the United Kingdom the effects are significant but smaller than in the United States. This appears to reflect the smaller share of stock ownership relative to other financial assets in these countries, as well as the more concentrated distribution of stock ownership across households in continental Europe when compared with the US."

\section{Background on Stock Price Movements and Household Wealth Developments in Industrial}

\section{Countries}

\section{Stock price developments and market capitalization}

As a first step for considering the possible role for stock market wealth on consumption, Figure 1 plots broad equity price indices for the major industrial countries from 1995 through December 2001. Equity prices in continental Europe rose markedly from January 1995, with gains in the late 1990s outstripping those in the United States as measured by the Wilshire 5000 index. In contrast, equity

\footnotetext{
${ }^{7}$ Boone, Giornio, and Richardson (1998) report estimates of consumption responses for G-7 countries using calibrated mpcs and supplement these estimates by estimating consumption equations that include changes in asset prices. Their empirical results support the conclusions based on calibrated mpcs, suggesting the largest consumption responses to equity price changes in the United States, and notably weaker responses in the continental European countries. Boone, Girouard, and Wanner (2001) find that differences in financial deregulation across countries can explain some of the differences in the consumption response to changes in wealth. Edison and Sløk (2001) investigate whether consumption responses measured as changes in retail sales differ across countries for movements in prices of "new economy" and "old economy" stocks; they conclude that the consumption response to "old economy" stock price movements is generally larger in Anglophone countries than in continental Europe, but the response to "new economy" valuations is roughly comparable across countries. Other recent examples include analysis by Goldman Sachs (2001), which calibrates the consumption response in the euro area to changes in equity wealth based on an estimated response of the saving rate to changes in the wealth-to-income ratio in the United States.
} 
prices in the United Kingdom and Canada increased somewhat less, and in Japan equity prices were unchanged on balance over most of this period. From mid 2000 through early 2002, equity prices in almost all industrial countries have declined about 20-30 percent.

However, even sizable movements in equity prices may have little effect on aggregate consumption if the total amount of outstanding equities is not large, or if they are not a significant portion of household wealth. The first column in Table 1 shows the estimated total stock market capitalization relative to GDP for several industrial countries in the fourth quarter of 1994, the fourth quarter of 1999, and the fourth quarter of 2001. In the United States and the United Kingdom, market capitalization in 1999 was in excess of 175 percent of GDP, and, reflecting in part the run-up in equity prices, capitalization increased notably from 1994 to 1999, although the decline in equity prices since 1999 has eroded market capitalization, especially in the United States. Market capitalization continues to be a somewhat smaller share of GDP in Australia, Canada, and Japan.

Equity issuance traditionally has not been an important form of corporate financing in the major continental European countries, and market capitalization traditionally has been much smaller. However, it grew significantly from 1994 to 1999, especially in France, where increased capitalization also reflects the flotations of shares of France Telecom and other newly-privatized industries. In some of the smaller European countries, for example in the Netherlands and Sweden, equity issuance has been a more important form of financing, and market capitalization remains sizable, although it has also declined relative to GDP since 1999.

The final column of the table shows the percentage-point change in the ratio of consumption to disposable income in these countries over the same period. In the United States, the United Kingdom, Canada, and Australia, the Netherlands, and Sweden, consumption growth has been robust over this period, and has grown appreciably faster than income, so that the ratio of consumption to income has increased between about 4 and 8 percentage points. In contrast, consumption has been less robust relative to income in the major continental European countries. In Japan, both consumption and income have grown little over this period, and the ratio of consumption to income has been little changed. This more rapid pace of consumption growth in the English-speaking countries, beyond the rate of income 
growth, is one indication analysts have pointed to assessing the relative magnitudes of wealth effects across the industrial countries.

\section{Household Wealth Developments}

Figures 2 and 3 show the evolution in household net worth, scaled by household disposable income, for these countries. ${ }^{8}$ In the United States, most of household net worth is held in financial assets, and the increase in financial assets relative to income in the second half of the 1990s is the major source of the rise total U.S. household net worth over this period; the decline in net worth in 2000 and 2001 also reflects movements in financial assets. An increase in both financial and nonfinancial wealth in the second half of the 1990s is also evident in the United Kingdom, but a more noticeable development is the housing market boom in the late 1980s and its subsequent collapse in the early 1990s. ${ }^{9}$ In Canada, household net worth has risen but by less than in the United States or the United Kingdom. In Japan, household net worth relative to disposable income has declined since the collapse of the bubble in asset prices in 1990, reflecting a sharp decline in the value of their real assets, while net financial wealth has risen somewhat over this period.

Figure 3 shows developments in household net worth for Germany, France, and Italy. In Germany, household net worth has been almost constant relative to household disposable income. ${ }^{10}$ In contrast to the other countries shown, most of German household wealth is held in the form of real estate, with only about 40 percent held as net financial assets, although this fraction has edged up in the past few years. Also in contrast to the United Kingdom and Japan, the value of wealth held in real assets has been little changed relative to income over the past decade. Financial assets through 2000 have risen more notably in France and Italy, where they now amount to more than 300 percent of disposable income.

\footnotetext{
8 These data are taken from Annex Table 57 in the OECD Economic Outlook 70: December 2001 and updated where possible with national source household sector balance sheet accounts.

${ }^{9}$ Asset price (in particular real estate) booms and subsequent collapses following rapid liberalization of financial markets also occurred in Finland, Norway, and Sweden in the early 1990s.

${ }^{10}$ The apparent drop in 1991 reflects breaks-in-series associated with the inclusion of data for East Germany beginning in that year.
} 
Figure 4 shows aggregate household financial asset data in more detail for the major industrial countries over the 1990s. ${ }^{11}$ In the United States, Canada, and the United Kingdom, increases in equities and in insurance and pension fund assets, which themselves are invested in part in equities, account for almost all of the increase in financial wealth in the 1990s. As a result of both increased flows into these assets in recent years, and, more importantly, the increased value of equity holdings resulting from capital gains, these assets made up more than half of aggregate household financial wealth in 1999. Likewise, the decline in equity prices starting in early 2000 has decreased the amount of wealth held in these assets, most notably for the United States and the United Kingdom.

In France, Germany, and Italy, holdings of equities and of insurance and pension fund assets are a much smaller share of household financial wealth, and aggregate holdings of these assets have increased less over the 1990s. ${ }^{12}$ In contrast to the other countries shown, the share of wealth held in equities in Japan has decreased somewhat since the early 1990s. ${ }^{13}$

The limited available evidence suggests that even in countries where equities are a sizable portion of aggregate household sector assets, they are still not held by most households. As indicated in the Table 2, the United States appears to have the widest ownership, with almost half of all U.S. households owning stocks either directly or indirectly through mutual funds and retirement accounts in 1998. Evidence from a Canadian poll suggested that a little over a third of Canadian households owned equities in some form in 1996. Survey data for the United Kingdom indicate that a somewhat smaller percentage of households held equities either directly or indirectly in 1995; nonetheless, this was a significant change from the mid 1980s when the share was closer to 7 percent. The most recent available surveys indicate that equities are quite narrowly held in France, Germany, and Italy. As has

\footnotetext{
${ }^{11}$ Household financial assets consist of equities, both those directly held, and, where they can be identified, those held through mutual funds; insurance and private pension fund assets; credit market instruments, corporate and government bonds, and other assets; and deposits in banks and other financial institutions.

12 In France the increase in insurance and pension fund assets between 1994 and 1996 primarily reflects the addition of asset categories not previously included in the balance sheet data, rather than flows into these assets or increases in their value.

13 There are notable breaks-in-series arising from changes to definitions of household sector wealth in France in 1999 and in Japan in 1998. The relatively limited impact on household sector financial wealth in Japan from the stock market decline in the early 1990s is largely accounted for by the limited amount of Japanese household wealth held in equities.
} 
occurred in the United States, the share of households owning equities is likely to have increased in most of these countries through the 1990s, reflecting easier access to equity ownership through mutual funds, as well as the enticement of the spectacular gains to be made in equity markets. Despite an increase in the proportion of households owning equities, recent gains in financial wealth from rising equity values in all of these countries are likely to have been felt predominantly by households in the upper end of the wealth distribution.

\section{Estimates of the effect of gains to financial wealth on consumption in foreign countries}

To understand the dynamics of spending in the industrial countries going forward, it is important to have some sense of how these changes to aggregate wealth will translate into changes to consumption. However, data limitations make this a difficult task, as comparable detailed information on household balance sheets generally is not available even for the major foreign industrial countries for sufficiently long time periods. Consequently, a number of different approaches are often employed to generate estimates of consumption responses to changes in wealth, especially stock market wealth. These approaches include calibration estimates based on the existing evidence for the United States, estimates using equity prices as a proxy for equity wealth, and estimates using wealth data itself. Estimates of consumption responses to changes in wealth for industrial countries using these three approaches are discussed in turn below. Estimates for the United States resulting from this study are not intended to be the last word or best estimate of the specific size of the U.S. wealth effect, because the data and model specifications used in this study are not as complete or detailed as has been suggested to generate more precise U.S. estimates. Instead, the data used are generally comparable to those available for the other industrial countries, so that U.S. results can be compared with those generated for the other countries. Even with a relatively simple consumption model, however, the results for the U.S. are consistent with conventional estimates of additional spending for each dollar of additional stock market wealth. 


\section{Calibration estimates}

A convenient and commonly employed method to gauge the consumption response to changes in equity wealth in foreign countries is to calibrate this response using conventional estimates of the U.S. marginal propensity to consume out of wealth and data on equity wealth from each country's national balance sheet accounts. The actual percentage-point change to consumption from a given change in stock market wealth depends on the elasticity of consumption with respect to wealth, so that even with the same marginal propensity to consume, consumption responses will be smaller in countries where the ratio of wealth to consumption is lower, or where a smaller share of financial wealth is held in the form of equities.

Table 3 calculates the implied consumption response this methodology would generate for a given change in equity prices in the G-7 countries plus Australia, Sweden, and the Netherlands. Line 1 shows how important equities were as a share of financial wealth in 1998 in this group of industrial countries. Line 2 calculates how much wealth would change if stock prices rise 10 percent, depending on the share of wealth held in equities. Lines 4, 5 and 6 calculate how much actual consumption would respond to this change in wealth, using a range of conventional estimates of the mpc. Based on 1998 wealth levels, if the consumption response to a dollar change in wealth is $3 \frac{1}{2}$ cents (an mpc of .035) in all countries, a 10 percent increase in equity prices would raise consumption in the long run by about 0.7 percent in both the United States and the United Kingdom. If the mpc was a bit larger-0.05-the consumption response would be about 1 percent in both countries. The estimated responses in Canada, Australia, and the Netherlands are a bit smaller. In France, Germany, and Italy, where equities remain a less important form of wealth, the consumption response is estimated to be between 0.1 percent and 0.3 percent. Even at an mpc of .075-on the high end of most estimates-the estimated consumption response in these countries still would be only about $1 / 4$ to $1 / 2$ percent.

These results suggest that the relative magnitude of the consumption response to a given change in stock prices may depend more on the share of equities in wealth and on the ratio of wealth to consumption than it will on differences in the mpc, so long as the mpcs fall within the range of common estimates. A benefit of this type of exercise is that it only requires the comprehensive aggregate wealth data for the foreign country household sectors for recent years and only on an annual basis, and as 
more foreign statistical agencies and central banks begin to produce such comparable balance sheet data, this method can be extended to cover additional countries. A drawback to this form of analysis is that there is no particular reason that the aggregate mpc out of wealth would necessarily be the same across countries. The aggregate mpc could vary according to the age structure of the population, the generosity of pension benefits, the distribution of wealth and income, and the importance of liquidity constraints.

\section{Estimates using stock price data}

A second method to estimate the effect on consumption from changes in stock market wealth is to relate consumption growth to changes in equity prices in an estimated reduced-form equation. An advantage to this approach is that equity price data are available for a sufficiently long time series-from at least the late 1970s to the present-for most countries considered. However, using equity prices has several limitations: a price index proxy cannot capture changes over time in the size of the equity market or in its importance in aggregate household wealth. Moreover, not all equity wealth in a given country is invested in domestic securities, so that changes in the value of these securities may not be well approximated by changes to a single domestic equity price index. Additionally, this measure does not capture changes to other forms of household wealth that may have significant effects on consumption, most importantly, changes to property wealth. Finally, changes in stock prices may influence consumption by serving as a leading indicator of activity and income growth, rather than through a direct effect on household wealth. ${ }^{14}$

To estimate the impact of a change in stock prices on consumption growth, the following regression equation relating changes in log real consumption to lagged changes in log real income and log real stock prices, and changes in real short-term market interest rates and the unemployment rate was estimated for each of the industrial countries covered in Table 3:

\footnotetext{
14 See Poterba and Samwick, (1995) for a discussion of this issue. Otoo (1999) documents the correlation between consumer sentiment and stock prices, and, using micro data, finds a correlation between sentiment and stock prices even for households that do not hold stocks, providing some support for a "leading indicator" role. For other industrial countries, there is little evidence of a strong correlation between consumer sentiment and stock prices.
} 


$$
d l c_{t}=\alpha_{0}+\sum_{i=1}^{4} \alpha_{1 i} d l c_{t-i}+\sum_{i=1}^{4} \alpha_{2 i} d l y_{t-i}+\sum_{i=1}^{2} \alpha_{{ }_{3 i}} d l s t k p_{t-i}+\sum_{i=1}^{2} \alpha_{{ }_{4 i}} d r_{t-i}+\sum_{i=1}^{2} \alpha_{{ }_{5 i}} d U R_{t-i}+\varepsilon_{t}
$$

This equation was estimated using quarterly data from 1979 through 1998 for the each of the industrial countries covered in Table 3. ${ }^{15}$ Table 4 summarizes the key results of this estimation. Changes in real stock prices were positive and significant at least at the ten percent level for seven of these countries, but insignificant in Canada, Japan, and Germany. While the findings for Germany and Japan are perhaps not surprising, given the relatively limited importance of equities in household wealth in these countries, the finding for Canada is surprising, as balance sheet data suggest that Canadian households do hold a relatively large share of their wealth in stocks, at least indirectly. One possible explanation may be that because the measure of Canadian equity prices-the Toronto 300 Composite index-is concentrated in natural resource industries, it does not properly capture changes in Canadian household wealth if Canadian inventors are more likely to hold globally diversified stock portfolios. The column marked Canada (2) of the table shows that when U.S. stock prices are substituted for the Canadian index, stock prices are positive and significant in explaining Canadian consumption. ${ }^{16}$

Line 3 of table 4 summarizes the estimated total consumption response generated by these models from a one-time 10 percent change in stock prices. The stock price change has in initial direct effect on consumption next quarter through the coefficients $\alpha_{3 \mathrm{i}}$ (sum $\Delta \log$ stock price in table 4), but if consumption also depends on its own lagged values, the total effect of the change in stock prices on consumption will persist longer, feeding through to consumption in future quarters through the $\alpha_{1 \mathrm{i}}$ terms (sum $\Delta \log$ consumption). ${ }^{17}$ These estimates generate increases in consumption of about 0.4 percent to 0.6 percent for the United States, the United Kingdom, and Canada (when using U.S. stock prices), 0.3 percent for the Netherlands and Sweden, and smaller responses ranging from 0.1 to 0.2 percent for

\footnotetext{
15 Data for Sweden are from 1981:Q2 to 1998:Q4. Stock price indices were deflated using the relevant country consumption deflator.

${ }^{16}$ However, this result could also reflect the integration of the Canadian and U.S. economies, rather than the effect of changes in wealth on consumption.

${ }^{17}$ The complete effect allowing for additional feed-through from the lagged consumption terms is calculated as $\sum \alpha_{3 \mathrm{i}} \times\left(1 /\left(1-\sum \alpha_{1 \mathrm{i}}\right)\right.$.
} 
Australia, France, Germany, Italy, and Japan. Except for the small and insignificant estimated response for Australia, these results are generally in line with those of Table 3: the largest responses are estimated for the three English-speaking countries where equities are an important form of household wealth. ${ }^{18}$ Among European countries, the estimated consumption responses are larger for the Netherlands and Sweden, where equities have become a relatively important form of household wealth, than for France, Germany, or Italy.

The recent downturn in stock prices has led some analysts to question whether short-run consumption responses may be more pronounced to decreases in wealth than to increases, as risk averse consumers may react more to decreases in wealth than to wealth increases of the same magnitude. To investigate this possibility, the same basic reduced-form regression was run, but with quarterly changes in stock prices separated into positive and negative movements. Lines 2 and 3 from the bottom of the table indicate that in some countries, especially the United States and Canada, consumption seems to respond more significantly-and by a greater amount-to stock price increases, but in others-in particular Japan-the response is more significant to price decreases. ${ }^{19}$

\section{Estimates using wealth data}

A third method for estimating consumption responses to developments in household wealth uses the aggregate household sector wealth data to estimate a long-run relationship between consumption, income, and wealth. ${ }^{20}$ However, this method can be used applied only to the subset of countries with a sufficiently long time series of quarterly wealth data. This study estimates this long-run relationship for

\footnotetext{
18 As with Canada, the insignificant result for Australia may also reflect the concentration of natural resource industries in the Australian equity price index.

${ }^{19}$ Shrivani and Wilbratte (2000) also find that short-run consumption responses to equity price declines are larger than responses to equity price increases in Japan, but find the negative response is also larger in Germany and in the United States. Their results may differ because of differences in model specification, differences in measures of stock prices and incomes, and differences in estimation samples.

${ }^{20}$ Under this model, households are assumed to follow a life-cycle model and base their consumption on their overall stock of wealth, including human capital wealth and financial and nonfinancial wealth. To estimate the model, researchers then must find a proxy for human capital wealth. Usually this is assumed to be proportional to current labor income, and so the empirical specification estimates consumption as a function of current income and current wealth. See Davis and Palumbo (2001) for a discussion of these issues.
} 
the United States, Australia, Canada, France, Japan, and the United Kingdom. Several variants-models A through D-were estimated, as the specification of wealth used varies somewhat across countries according to data availability. In model A, the measure of wealth is total household sector wealth, an aggregate measure that includes both financial and non-financial wealth. This measure of wealth is the only measure that could be obtained for Australia, and for comparison purposes a version of Model A was also estimated for the United States, the United Kingdom, and Canada. Models that use a measure of financial wealth only (no data could be obtained for nonfinancial wealth) are identified as Model B (France and Japan). Where both financial wealth and nonfinancial wealth are available separately (the United States, the United Kingdom, and Canada), Model C includes both measures entered separately. Finally, because many of the U.S. results are based specifically on equity wealth, an additional set of U.S. and Canadian regressions were estimated, differentiating between equity wealth (including equity held indirectly in defined-contribution pension funds) and all other wealth (Model D). For all U.S. models, the measure of income is non-capital real disposable income. For other countries, the income measure used is a measure of household income: either personal disposable income, compensation of employees, or wage and salary income.

For each country, these regressions are estimated through a two-stage error-correction model. ${ }^{21}$ In the first stage, a long-run cointegrating relationship between the log-levels of consumption, income, and wealth is estimated using Stock and Watson's procedure of including leads and lags of the changes in income and wealth to adjust for simultaneity. In the second stage, consumption growth is estimated as a function of lagged values of consumption growth, lagged values of real disposable income growth, real wealth growth, the change in a real 3-month interest rate, and the change in the unemployment rate. For each country, the consumption growth equation also includes the residuals from the error-correction equation estimated in the stage one regression.

Studies that have looked at the United States show that estimates of the long-run relationship can be sensitive to the time period selected. To estimate a long-run relationship, it is usually desirable to select the longest time series available. For the United States, the sample includes consumption,

\footnotetext{
21 Appendix I looks at evidence on whether or not these variables are trend stationary and for evidence that consumption, income, and wealth are cointegrated. Except for France, the results generally support the assumption of cointegration.
} 
income, and wealth data from 1960 to the present. However, for several of the foreign countries, data are only available from the 1970s or 1980s. Moreover, as noted below, coefficient estimates for some of the foreign countries are especially unstable early in the samples, and in some cases more sensible results are generated over samples estimated from the mid-1970s or the 1980 s only. ${ }^{22}$

\section{Long-run results}

Table 5 lists the key results from these first-stage regression equations. In all of the countries considered-Australia, Canada, France, Japan, the United Kingdom, and the United States-the coefficients on both income and on the broadest form of wealth available are significant in at least some of the specifications of the log-level regressions, although the findings for wealth for France are not robust to sample period and model specification. Additionally, for the United States and Canada, where it is possible to distinguish equity from non-equity wealth and financial from non-financial wealth, the coefficients on equity and on financial wealth are both significant. In similar equations for the United States, the coefficients on non-equity and non-financial wealth-consisting primarily of residential housing-are also significant, but non-financial wealth entered separately is not significant in the Canadian regressions. For the United Kingdom, where net financial wealth can be distinguished from housing wealth, both forms of wealth enter significantly into the long-run equation.

The coefficients on the log-levels of income and wealth can be interpreted as the implied longrun elasticities of consumption with respect to the given measures of income and wealth. Because these measures differ across countries, the estimated elasticities are not necessarily comparable, but some general observations can be drawn. In all countries, the long-run elasticity with respect to income is significantly larger than that for wealth, and generally ranges from about 0.6 to 0.9 . For wealth, the elasticities range from 0.06 for narrowly-defined forms of wealth in some countries to 0.4 for some broad definitions of wealth.

\footnotetext{
22 A difficulty in using the foreign wealth data is that there appear to be several breaks-in-series and changes in coverage that are not well documented. This may be one of the reasons for unstable results using early years of data.
} 
Tables 6 and 7 calculate the implied long run marginal propensity to consume out of wealth that these models generate. ${ }^{23}$ For the United States, these estimates are close to 0.06 for total wealth (table 6, line 3, Model A) and for both financial wealth and equity wealth (table 6, line 3, Models C and D), and slightly higher (about 0.075 to 0.1 ) for non-financial or non-equity wealth (table 7 , line 3 , Models $\mathrm{C}$ and D). Thus, these results for financial wealth imply a consumption response to changes in wealth in the United States that is only a little higher than the conventional wisdom that the U.S. marginal propensity to consume out of stock market wealth is " 3 to 5 cents on the dollar," and imply a somewhat larger response to changes in nonfinancial or non-equity wealth. For the United Kingdom, the estimated mpcs for total, financial, and housing wealth are all about 0.04 , slightly lower than those in the United States. For Canada, the estimates for the mpc's out of total and financial wealth are larger, in the 0.08-0.1 range, but the estimated responses to non-financial wealth are not significant. ${ }^{24}$ The results for Japan are also yield an mpc for financial wealth of about 0.1. For Australia and France, the estimated mpcs are about 0.05 and 0.03 , respectively.

The consumption response from a given change in stock prices that these estimated mpcs imply cannot easily be compared across countries, because the fraction of household wealth held in equities differs across countries and across measures of wealth, so that the different measures of wealth themselves respond differently to equity price changes. To compare the results across countries and with the consumption responses from the calibration exercises and stock price estimates in Tables 3 and 4 more directly, lines 5 through 7 of Table 6 calculate how much the various measures of wealth in each country would increase if equity prices rise 10 percent, and then calculate the implied consumption

\footnotetext{
${ }^{23}$ Under the log-level specification, an underlying assumption is that the long-run elasticity of consumption to wealth and to income is constant. The implied marginal propensity to consume out of wealth that these estimates generate will differ over time if there are notable changes to the ratio of wealth to consumption. Recursive estimation of the long-run consumption equations indicated that for most countries this was a reasonable assumption, with the notable exception of Canada in the earlier part of the sample, as noted in footnote 18 below, and France. See Davis and Palumbo (2001) for a discussion of the interpretations of parameter estimates from different long-run model specifications.

${ }^{24}$ Under some specifications, the estimated coefficient on non-financial wealth is negative but insignificant. The reported Canadian results are estimated over the period 1976-2000. Data extending back to 1961 are available, but including these earlier data yielded very unstable results. Recursive estimation shows that the estimated coefficients on income range from 0.2 to 0.7 , while the coefficients on wealth are similarly variable. Chow tests also indicated numerous breaks when these earlier data are included.
} 
response from this increase in wealth. Using the estimated share of equities both directly and indirectly held through mutual funds, insurance, and pension funds as of the end of 1998, a 10 percent increase in U.S. equity prices would translate to a 3.7 percent increase in total U.S. wealth, a $4 \frac{1}{2} 2$ percent increase in financial wealth, and an 8 percent increase in the measure of equity wealth. ${ }^{25}$ Accounting also for the different wealth-to-consumption ratios for the different measures of wealth and the different estimated mpcs out of the different measures of wealth, line 7 shows the estimated long-run consumption response from a permanent 10 percent increase in stock prices. The calculations across all measures of wealth yield very consistent results for the United States of an increase in consumption of 1.2 to 1.4 percent.

For the United Kingdom, the long-run consumption response is a little smaller, ranging from 0.8 to 0.9 percent depending on the equation specification, while for Canada they are somewhat larger, ranging from 1.6 to almost 2 percent. ${ }^{26}$ For Australia, the estimated consumption response is about $1 / 2$ percent. Although the estimated mpc to consume out of changes to wealth is somewhat higher in Japan than in other countries considered, equities remain relatively unimportant in Japanese household wealth, so the estimated consumption response to a 10 percent stock price change is only $1 / 2$ percent. The estimated response is lowest in France-0.3-as both the mpc and the share of equities in household wealth are smaller. In general, these long-run responses are a bit larger than the short-run consumption responses reported in Table 4, but overall support the conclusions of larger consumption responses for the United States, the United Kingdom, and Canada, and smaller responses in Japan, Australia, and continental Europe.

Table 7 uses the same methodology to calculate the long-run consumption response for a change to housing wealth, for those countries that have a measure of non-financial wealth. For the United States, these estimates generate an estimated increase in consumption from a permanent 10 percent increase in housing prices of 0.7 to 1 percent. For the United Kingdom, these estimates are

\footnotetext{
25 The change in "equity" wealth is not quite 10 percent, because this measure of wealth includes all assets in retirement accounts and mutual funds, not all of which are actually equities.

${ }^{26}$ By comparison, the Bank of England's model suggests that in the long run, U.K. consumption increases 0.7 percent for a 10 percent increase in net financial wealth. The estimates presented here imply a somewhat larger consumption response to a 10 percent increase in net financial wealth-on the order of 1.4 to 1.5 percent-as a 10 percent increase in net financial wealth would require a increase in stock prices of more than 10 percent.
} 
also about 1 percent. Based on total wealth or non-equity wealth, these estimates generate a 1 percent increase in consumption for Canada. ${ }^{27}$ For Australia, the estimated increase is a bit larger at about 1.6 percent.

\section{Consumption growth equations}

The second stage estimation relates changes in log consumption to its own lags, lagged changes in log real income and log real wealth, lagged changes in real short-term interest rates and the unemployment rate, and the lagged estimated residual from the first-stage error correction regression:

$$
\begin{aligned}
& d l c_{t}=\alpha_{0}+\sum_{i=1}^{4} \alpha_{1 i} d l c_{t-i}+\sum_{i=1}^{4} \alpha_{2 i}{ }_{2 l} y_{t-i}+\sum_{i=1}^{2} \alpha_{3 i} \text { dlwealth }_{t-i}+ \\
& \sum_{i=1}^{2} \alpha_{{ }_{4 i}} d r_{t-i}+\sum_{i=1}^{2} \alpha_{{ }_{5 i}} d U R_{t-i}+\alpha_{6} E C M+\varepsilon_{t}
\end{aligned}
$$

In all of the countries except France, the coefficient on the error-correction residual term is significant and negative in explaining consumption growth (Table 8), so that consumption growth is boosted when this residual is negative, i.e., if the log-level of consumption in the previous period has fallen short of its estimated long-run value in relation to current income and wealth. For France, the coefficient has the expected negative sign but is significant at only the 14 percent level. In all cases the coefficient on the lagged residual term-the speed of adjustment coefficient-is considerably less than 1 , so that the adjustment of current consumption to imbalances between the level of consumption, income, and wealth is slow, typically taking 2 to 4 years for a change in income or wealth to feed through to consumption. Only a fraction is felt in the first quarter, and on average about half of the total effect is felt after the first year, and three-quarters within two years. Moreover, if equity or other asset prices rise and then fall, the effect on consumption is smoothed, as most households will not have adjusted their consumption completely to the most recent increase in wealth, and so will not have to adjust as much to bring consumption back in line if wealth declines.

\footnotetext{
27 No estimate of the consumption response is reported for Canada model C because the coefficient on non-financial wealth was insignificant.
} 


\section{Additional short-run effects of wealth and asset prices}

In addition to the effect on consumption growth noted above through the error-correction residual term, the consumption growth equations also allow for short-run effects on consumption growth through changes in wealth. For the United States, following an increase in stock prices of 10 percent-which would translate to an increase in wealth of between 3.7 and 7.8 percent, depending on the measure of wealth used, consumption the next quarter would be boosted temporarily by about $1 / 2$ percent. Additional effects would be felt over the next few quarters, as current consumption responds to lagged consumption. For Canada, the estimated initial consumption response is considerably larger-about 1 percent. Changes to financial wealth did not have additional short-run effects in the United Kingdom, Japan, or Australia, but changes to property wealth do have significant short-run effects for the United Kingdom and Japan. For changes in both financial and non-financial wealth, these short-run effects die out over time, and the only lasting effect of wealth on the level of consumption comes from a permanent change to the level of wealth through the error-correction mechanism.

\section{Can these equations capture movements in consumption in the United States, Canada, and} the United Kingdom in the 1990s and early 2000s?

Over the past decade wealth has moved notably in three countries where wealth effects seem to matter the most: the United States, Canada, and the United Kingdom. Can these consumption growth equations capture the basic contours of actual consumption behavior over this period? Chart 5 plots actual quarterly consumption growth, fitted consumption growth (expressed at an annual rate) from the best-fitting consumption growth equations from Table 8, and the out-of-sample dynamic forecast from these equations for 2000 and 2001. For quarterly consumption growth, there may be significant errors at particular times because these models are fairly simple.

For the United States, the estimated model captures the increase in actual U.S. quarterly consumption growth from about 3 percent (annual rate) in the mid-1990s to about 5 percent in the late 1990s (panel A). Using the model to forecast ahead over the 2000 and 2001, it also captures the more 
recent deceleration in U.S. consumption growth. ${ }^{28}$ Panel B repeats this exercise for Canada. Compared with the United States, Canadian consumption increased less over the 1990s, in part reflecting the more moderate step-up in Canadian wealth. The model also forecasts a down-turn in Canadian consumption especially in 2001, but the decrease is predicted to be less pronounced than for the United States, in part because the change to wealth-both on the upside and on the downside-has been less dramatic.

Panel C shows results for the United Kingdom. The estimated U.K. model captures well the consumption cycle associated with the housing price boom and subsequent collapse in the late 1980s and early 1990s. The model also captures the recovery in consumption growth as wealth picked up again in 1997 and 1998. However, the model does less well at capturing U.K. consumption growth in 2000 and 2001. Although U.K. household wealth has not declined to the extent that U.S. wealth has-in large part reflecting a robust U.K. housing market-it has stopped increasing at the rate it had over the second half of the 1990s, and even unchanged wealth is predicted to slow consumption growth. It may be that because the model primarily captures long-term movements, it is temporarily off-track (as was the case for the U.S. model during the early 1990s recession, and as was the Canadian model in 1992 and 1993). ${ }^{29}$ Current estimates of U.K. wealth, consumption, and income may also be subject to revision, and the current deviation may be less glaring as data are revised. It is also worth noting that the deviation of model forecast from actual is only outside of the 95 percent confidence bands for $2001 \mathrm{Q} 3 .^{30}$

\footnotetext{
28 Although U.S. consumption growth did slow in 2000, the model under-predicts the robust 3.7 percent (annual rate) pace of actual consumption growth in the second half of 2001. Two factors that supported consumption growth over this period that are not accounted for in this model are the tax cuts enacted in 2001 and accompanying tax rebates given out over the summer, and the unusually generous financing incentives offered for motor vehicle purchases later in the year.

${ }^{29}$ In its November 2001 Inflation Report, the Bank of England's Monetary Policy Committee noted that in mid-2001, consumption relative to current income remained "unusually large" by historical standards, and suggested that changes to current income may understate changes to expected lifetime resources. Nonetheless, the Bank of England expected consumption growth to slow in the near term, reflecting in part the decline in household financial wealth.
}

${ }^{30}$ An often-mentioned explanation for the relatively robust consumption response in the United Kingdom has been the recent strength of the U.K. housing market, and an asymmetric consumption response to housing price increase and decreases. Such an asymmetric response could arise if housing price increases encourage households 


\section{Conclusions}

This paper investigates the strength of the wealth effect on consumption arising primarily from higher equity values in foreign industrial countries. I present results from calibration estimates, using equity prices as a proxy for wealth held in equities, and, where data are available, using household sector wealth itself. Wealth effects, especially those arising from equity wealth, are found to be quite significant in several foreign industrial countries. In Canada and the United Kingdom, the estimated consumption responses to a given change in equity prices are comparable-or even a little larger-than for the United States. The wealth channel also appears to be important in explaining Japanese consumption behavior. In continental European countries, the results presented here suggest more modest consumption responses, reflecting the relatively small shares that equities still occupy in aggregate household wealth. However, in some of the smaller European countries where equity financing is more common and equities are becoming more important in household wealth, such as in Sweden and the Netherlands, wealth effects appear to be important.

In Canada and the United Kingdom, consumption in the second half of the 1990s has been robust, but on average has grown somewhat less than in the United States. In part, this reflects the less impressive performance in U.K. and Canadian equity markets over the 1990s when compared with U.S. markets, as illustrated in figure 1. Additionally, disposable income has grown somewhat less in these countries than in the United States, and income expectations may have grown less as well. In continental European countries, the more modest consumption responses observed in the late 1990s are consistent a less important role for wealth effects on consumption. However, the run-up in European equity prices was especially spectacular in 1999, and even with a relatively small elasticity, some effect on consumption would be expected. In contrast to the early 1990s, Japanese household wealth has changed little over the past few years, and the wealth channel appears to have been relatively unimportant in explaining recent Japanese consumption.

\footnotetext{
to tap into the increase in housing equity through second mortgages. To investigate this possibility, the short-run U.K. model was also estimated with housing price increases included separately from housing price decreases. However, there was no significant difference in the estimated coefficients for prices entered this way, and the resulting model performed no better in forecasting U.K. consumption. The primary reason for the projected slowdown in U.K. consumption growth is the emergence of a sizable positive residual from the long-run levels equation, as the level of consumption has deviated from its long-run relationship to income and total wealth.
} 
Since early 2000, equity prices in industrial countries have declined on average 20-30 percent, and as 2001 figures become available, household financial wealth relative to income will likely have fallen even more notably than it did in 2000. As consumption in the industrial countries benefitted from the increase in wealth over the latter half of the 1990s, it can be expected to be held back by the erosion of wealth over the past two years. However, because the error-correction results suggest that consumption responds relatively slowly to either wealth or income changes, consumption most likely will not have responded completely to the most recent run-up in equity prices. Additionally, wealth held in the form of residential housing has continued to appreciate, especially in the United Kingdom but also in the United States. This increase to non-financial wealth may help cushion the effects on consumption of the decline in equity wealth.

As equity ownership becomes more widespread, estimates of the effect on aggregate consumption of a dollar change in equity wealth may change. Different segments of the population may respond differently to changes in equity wealth, because of differences in income expectations, the presence of liquidity or credit constraints, and influences from other sources of wealth. To this end, recent approaches that look at micro data and attempt to reconcile responses for population subgroups with what we observe at the aggregate level are likely to be informative. An understanding of the interplay of these effects is likely to be especially important in assessing the impact of changes in household wealth in European countries, where equity ownership is growing and has only recently become an important form of household wealth. 
Table 1.

Estimated Total Market Capitalization, as share of GDP, and change in ratio of consumption to disposable income, selected industrial countries

\begin{tabular}{|c|c|c|c|c|}
\hline & \multicolumn{3}{|c|}{ Market Capitalization, as share of GDP } & \multirow{2}{*}{$\begin{array}{c}\text { Percentage Point } \\
\text { change in Ratio of } \\
\text { Consumption to } \\
\text { Disposable Income } \\
\text { 1994Q4-1999Q4 }\end{array}$} \\
\hline & 1994-Q4 & 1999-Q4 & 2001-Q4 & \\
\hline United States & 76 & 180 & 130 & 4.4 \\
\hline United Kingdom & 110 & 194 & 153 & 3.9 \\
\hline Canada & 56 & 112 & 90 & 5.6 \\
\hline Australia & 35 & 103 & 103 & 4.6 \\
\hline Netherlands & 45 & 190 & 148 & 5.0 \\
\hline Sweden & 93 & 155 & 114 & 8.0 \\
\hline France & 31 & 101 & 89 & -.5 \\
\hline Germany & 21 & 72 & 59 & 2.2 \\
\hline Italy & 17 & 60 & 48 & -.4 \\
\hline Japan & 77 & 97 & 62 & 1.0 \\
\hline
\end{tabular}


Table 2.

Share of Households Owning Equities

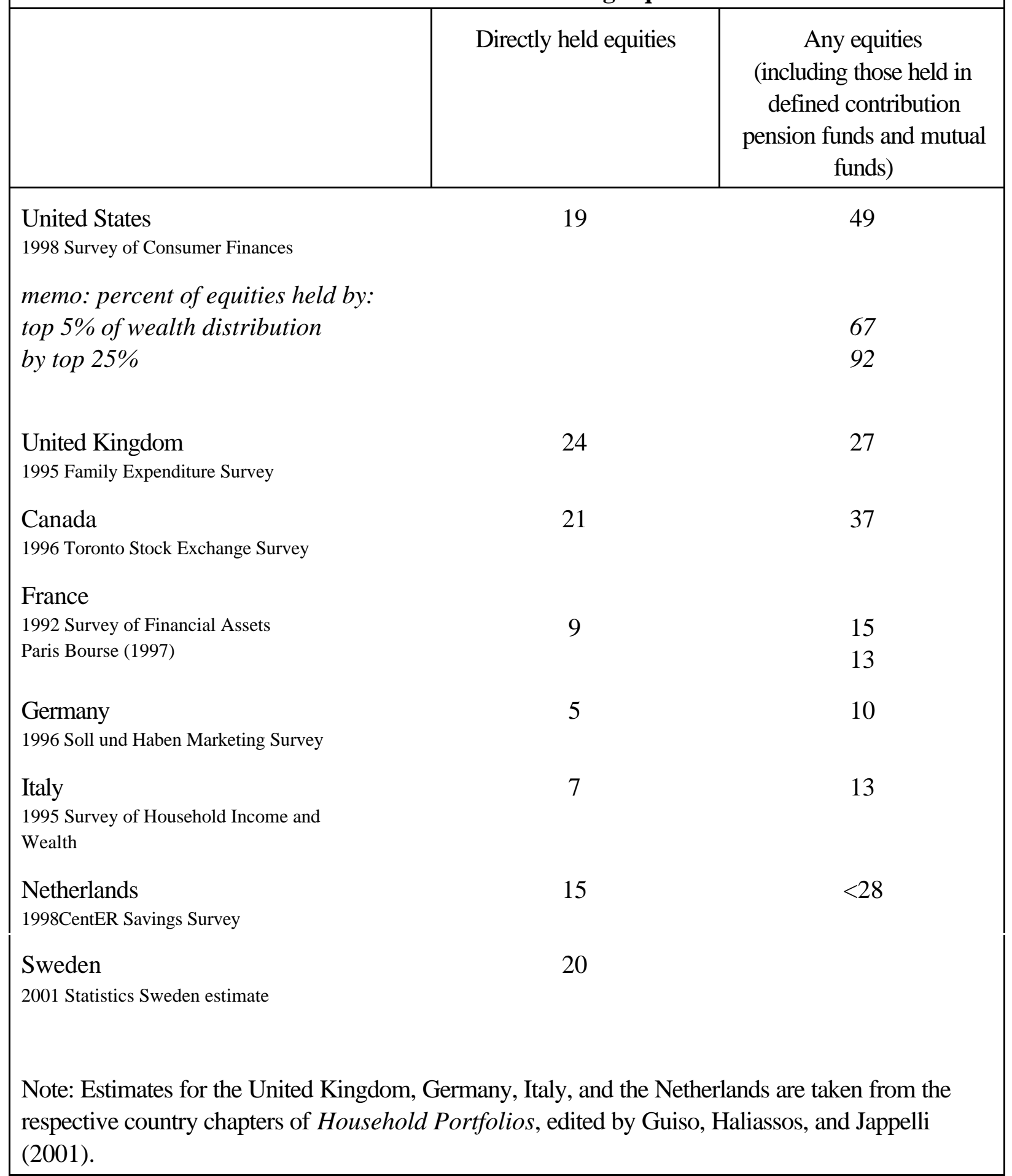


Table 3.

Calibrated long-run consumption responses in industrial countries to a 10 percent stock price increase, assuming alternate magnitudes of the marginal propensity to consume out of wealth

\begin{tabular}{|c|c|c|c|c|c|c|c|c|c|c|}
\hline & $\begin{array}{l}\text { United } \\
\text { States }\end{array}$ & $\begin{array}{c}\text { United } \\
\text { Kingdom }\end{array}$ & Canada & Australia & Japan & France & Germany & Italy & Netherlands & Sweden \\
\hline $\begin{array}{l}\text { 1. Share of equities in financial } \\
\text { wealth in } 1998\end{array}$ & .38 & .42 & .32 & .45 & .17 & .16 & .15 & .20 & .30 & .43 \\
\hline $\begin{array}{l}\text { 2. Implied percentage-point } \\
\text { change to equity wealth from a } \\
10 \text { percent increase in stock } \\
\text { prices }\end{array}$ & 3.8 & 4.2 & 3.2 & 4.5 & 1.7 & 1.6 & 1.5 & 2.0 & 3.0 & 4.3 \\
\hline $\begin{array}{l}\text { 3. Financial Assets / } \\
\text { Consumption in } 1998\end{array}$ & 5.2 & 4.8 & 3.8 & 2.5 & 4.6 & 3.4 & 2.4 & 3.7 & 6.0 & 2.3 \\
\hline $\begin{array}{l}\text { 4. Implied percentage-point } \\
\text { consumption response, } \\
\text { assuming an mpc of } 0.035 \\
=\text { line }(2) \times \text { line }(3) \times .035\end{array}$ & 0.7 & .07 & 0.4 & 0.4 & 0.3 & 0.2 & 0.1 & 0.3 & 0.6 & .4 \\
\hline $\begin{array}{l}\text { 5. Implied percentage-point } \\
\text { consumption response, } \\
\text { assuming an mpc of } 0.05 \\
=\text { line }(2) \times \text { line }(3) \times .05\end{array}$ & 1.0 & 1.0 & 0.6 & 0.6 & 0.4 & 0.3 & 0.2 & 0.4 & 0.9 & .5 \\
\hline $\begin{array}{l}\text { 6. Implied percentage-point } \\
\text { consumption response, } \\
\text { assuming an mpc of } 0.075 \\
=\text { line }(2) \times \text { line }(3) \times .075\end{array}$ & 1.5 & 1.5 & 0.9 & 0.8 & 0.6 & 0.4 & 0.3 & 0.6 & 1.4 & .7 \\
\hline
\end{tabular}

Data for Sweden are 1997. For France, Germany, Italy, the Netherlands, and Sweden, the estimate of the share of equities in financial wealth includes an estimate

of equities held indirectly through defined contribution pensions and life insurance accounts. 
Table 4. Results from reduced-form regression equations for the effect of changes in stock prices on consumption growth

\begin{tabular}{|c|c|c|c|c|c|c|c|c|c|c|c|}
\hline & $\begin{array}{l}\text { United } \\
\text { States }\end{array}$ & $\begin{array}{c}\text { United } \\
\text { Kingdom }\end{array}$ & Canada & $\begin{array}{l}\text { Canada } \\
\text { (2) }\end{array}$ & Japan & Australia & France & Germany & Italy & Nether. & Sweden \\
\hline sample period & $\begin{array}{l}\text { 1979:Q1- } \\
\text { 1998:Q4 }\end{array}$ & $\begin{array}{l}\text { 1979:Q1- } \\
\text { 1998:Q4 }\end{array}$ & $\begin{array}{l}\text { 1979:Q1- } \\
\text { 1998:Q4 }\end{array}$ & $\begin{array}{l}\text { 1979:Q1- } \\
\text { 1998:Q4 }\end{array}$ & $\begin{array}{l}\text { 1979:Q1- } \\
\text { 1998:Q4 }\end{array}$ & $\begin{array}{l}\text { 1979:Q1- } \\
\text { 1998:Q4 }\end{array}$ & $\begin{array}{l}\text { 1979:Q1- } \\
\text { 1998:Q4 }\end{array}$ & $\begin{array}{l}\text { 1979:Q1- } \\
\text { 1998:Q4 }\end{array}$ & $\begin{array}{l}\text { 1979:Q1- } \\
\text { 1998:Q4 }\end{array}$ & $\begin{array}{l}\text { 1979:Q1- } \\
\text { 1998:Q4 }\end{array}$ & $\begin{array}{l}\text { 1981:Q2 } \\
\text { 1998:Q4 }\end{array}$ \\
\hline Sum $\Delta \log$ stock price & $.048 *$ & $.036^{*}$ & .009 & $.033 *$ & .012 & .017 & $.022 *$ & .009 & $.010 * *$ & $.036+$ & $.028 *$ \\
\hline Sum $\Delta \log$ consumption & $.261+$ & .190 & $.502 *$ & $.456 *$ & $.450 * *$ & $.134 *$ & -.397 & -.235 & $.527 * *$ & $-.279 * *$ & -.079 \\
\hline $\begin{array}{l}\text { Consumption response from } \\
10 \text { percent stk price increase }\end{array}$ & .64 & .44 & .18 & .61 & .22 & .19 & .16 & .07 & .21 & .28 & .26 \\
\hline Sum $\Delta$ Housing/Land prices & -.048 & .025 & & & .043 & & & & & & \\
\hline $\mathrm{R}^{2}$ & .523 & .351 & .475 & .505 & .626 & .269 & .296 & .747 & .695 & .435 & .505 \\
\hline
\end{tabular}

Using positive and negative stock price changes separately:

\begin{tabular}{|c|c|c|c|c|c|c|c|c|c|c|c|}
\hline Sum $\Delta \log$ stk price positive & $.095 * *$ & $.043^{*}$ & .048 & $.063+$ & -.010 & .007 & $.038+$ & -.023 & .009 & .035 & $.047 * *$ \\
\hline Sum $\Delta \log$ stk price negative & -.012 & .028 & -.026 & -.001 & $.040+$ & $.015+$ & .005 & .039 & .011 & .040 & .000 \\
\hline Sum $\Delta \log$ Consumption & $.265+$ & .194 & $.542 * *$ & $.524 *$ & $.372 *$ & .131 & -.450 & -.240 & $.526 * *$ & $-.290 * *$ & -.074 \\
\hline $\begin{array}{l}\text { Consumption response from } \\
10 \text { percent stk price increase }\end{array}$ & 1.29 & .54 & 1.09 & 1.32 & -.17 & .08 & .26 & -.19 & .19 & .27 & .44 \\
\hline $\begin{array}{l}\text { Consumption response from } \\
10 \text { percent stk price decrease }\end{array}$ & .16 & -.35 & .56 & .14 & -.63 & -.17 & -.03 & -.31 & -.23 & -.31 & .00 \\
\hline $\mathrm{R}^{2}$ & .579 & .374 & .500 & .522 & .646 & .302 & .313 & .752 & .695 & .436 & .522 \\
\hline
\end{tabular}

+ Coefficient significant at 10 percent; * Coefficient significant at 5 percent; $* *$ Coefficient significant at 1 percent Consumption response significant at 10 percent or greater in bold

Regression equations included 3 lags of the change in log real consumption, 3 lags of the change in log real income, 2 lags of the change in log real stock prices,

1 lag of the change in real short-term interest rates, 1 lag of the change in the unemployment rate, and dummy variables for 1980Q2 and 1991Q1, and for 1997Q1

\& Q2 for Japan. 


\begin{tabular}{|c|c|c|c|c|c|c|c|c|c|c|c|}
\hline \multicolumn{12}{|c|}{$\begin{array}{l}\text { Table } 5 . \\
\text { Key results from first-stage regressions for consumption levels }\end{array}$} \\
\hline & \multicolumn{3}{|c|}{ United States } & \multicolumn{2}{|c|}{ United Kingdom } & \multicolumn{3}{|c|}{ Canada } & \multirow{2}{*}{$\begin{array}{c}\text { Japan } \\
\text { Model } \\
\text { (B) }\end{array}$} & \multirow{2}{*}{$\begin{array}{c}\text { France } \\
\begin{array}{c}\text { Model } \\
\text { (B) }\end{array}\end{array}$} & \multirow{2}{*}{$\begin{array}{c}\text { Australia } \\
\text { Model } \\
\text { (A) }\end{array}$} \\
\hline & $\begin{array}{l}\text { Model } \\
\text { (A) }\end{array}$ & $\begin{array}{l}\text { Model } \\
\text { (C) }\end{array}$ & $\begin{array}{l}\text { Model } \\
\text { (D) }\end{array}$ & $\begin{array}{l}\text { Model } \\
\text { (A) }\end{array}$ & $\begin{array}{l}\text { Model } \\
(\mathrm{C})\end{array}$ & $\begin{array}{l}\text { Model } \\
\text { (A) }\end{array}$ & $\begin{array}{l}\text { Model } \\
(\mathrm{C})\end{array}$ & $\begin{array}{l}\text { Model } \\
\text { (D) }\end{array}$ & & & \\
\hline sample period & $\begin{array}{l}\text { 1960:Q1- } \\
\text { 2000:Q4 }\end{array}$ & $\begin{array}{l}\text { 1960:Q1- } \\
\text { 2000:Q4 }\end{array}$ & $\begin{array}{l}\text { 1960:Q1- } \\
\text { 2000:Q4 }\end{array}$ & $\begin{array}{l}\text { 1970:Q1- } \\
\text { 2000:Q3 }\end{array}$ & $\begin{array}{l}\text { 1970:Q1- } \\
\text { 2000:Q3 }\end{array}$ & $\begin{array}{l}\text { 1976:Q1- } \\
\text { 2000:Q4 }\end{array}$ & $\begin{array}{l}\text { 1976:Q1- } \\
\text { 2000:Q4 }\end{array}$ & $\begin{array}{l}\text { 1976:Q1- } \\
\text { 2000:Q4 }\end{array}$ & $\begin{array}{l}\text { 1980:Q2- } \\
\text { 2000:Q4 }\end{array}$ & $\begin{array}{l}\text { 1978:Q1- } \\
\text { 1998:Q4 }\end{array}$ & $\begin{array}{c}\text { 1981:Q1- } \\
\text { 1999:Q2 }\end{array}$ \\
\hline Log income & $\begin{array}{c}.742 \\
(8.083)\end{array}$ & $\begin{array}{c}.663 \\
(6.931)\end{array}$ & $\begin{array}{c}.669 \\
(8.239)\end{array}$ & $\begin{array}{c}.617 \\
(6.150)\end{array}$ & $\begin{array}{c}.651 \\
(6.053)\end{array}$ & $\begin{array}{c}.634 \\
(3.436)\end{array}$ & $\begin{array}{c}.746 \\
(4.891)\end{array}$ & $\begin{array}{c}.700 \\
(7.298)\end{array}$ & $\begin{array}{c}.866 \\
(5.216)\end{array}$ & $\begin{array}{c}.802 \\
(2.831)\end{array}$ & $\begin{array}{c}.770 \\
(4.300)\end{array}$ \\
\hline Log total wealth & $\begin{array}{c}.289 \\
(3.726)\end{array}$ & & & $\begin{array}{c}.195 \\
(3.800)\end{array}$ & & $\begin{array}{c}.407 \\
(3.758)\end{array}$ & & & & & $\begin{array}{c}.219 \\
(2.597)\end{array}$ \\
\hline Log financial wealth & & $\begin{array}{c}.230 \\
(5.032)\end{array}$ & & & $\begin{array}{c}.088 \\
(2.665)\end{array}$ & & & $\begin{array}{c}.340 \\
(7.417)\end{array}$ & $\begin{array}{c}.285 \\
(3.828)\end{array}$ & $\begin{array}{c}.101 \\
(2.034)\end{array}$ & \\
\hline $\begin{array}{l}\text { Log non-financial } \\
\text { wealth }\end{array}$ & & $\begin{array}{c}.136 \\
(3.072)\end{array}$ & & & $\begin{array}{c}.092 \\
(2.426)\end{array}$ & & & $\begin{array}{c}-.112 \\
(-1.161)\end{array}$ & & & \\
\hline Log equity wealth & & & $\begin{array}{c}.099 \\
(5.039)\end{array}$ & & & & $\begin{array}{c}.139 \\
(2.915)\end{array}$ & & & & \\
\hline $\begin{array}{l}\text { Log non-equity } \\
\text { wealth }\end{array}$ & & & $\begin{array}{c}.281 \\
(3.276)\end{array}$ & & & & $\begin{array}{c}.155 \\
(1.715)\end{array}$ & & & & \\
\hline
\end{tabular}




\section{Table 5: Notes}

All equations estimated using log levels of real consumption, real income, and real wealth, using the "leads and lags" procedure suggested by Stock and Watson. Adjusted t-statistics in parentheses. Coefficients on led and lagged difference variables not shown.

Income variables: United States: non-capital personal disposable income. Canada: wage and salary income. United Kingdom: personal disposable income. Australia: personal disposable income. Japan: compensation of employees. France: personal disposable income. For countries where only nominal income was available, real disposable income was estimated by deflating nominal income by the consumption deflator.

Wealth variables were taken from household and non-profit sector balance sheet accounts, and were deflated using relevant country consumption deflators. Model A: estimation uses a measure of total household sector wealth. (United States, United Kingdom, Canada, and Australia. For Australia, the measure is total household sector assets (not net of liabilities)).

Model B: estimation uses a measure of household sector financial wealth only (Japan, France).

Model C: estimation uses a measure of total wealth, with financial wealth and non-financial wealth entered separately. For the United Kingdom, non-financial wealth includes only housing wealth (United States, the United Kingdom, and Canada).

Model D: estimation uses a measure of total household sector wealth held in equities, and a measure of all other household sector wealth. Equity wealth includes directly-held equity, plus household sector the mutual fund holdings and defined-contribution pension funds (United States and Canada). 


\begin{tabular}{|c|c|c|c|c|c|c|c|c|c|c|c|}
\hline \multicolumn{12}{|c|}{$\begin{array}{l}\text { Table } 6 . \\
\text { Estimated long-run consumption response to permanent } 10 \text { percent increase in stock prices, } \\
\text { Using estimated LR coefficients on log level financial wealth from ECM stage } 1 \text { regressions }\end{array}$} \\
\hline & \multicolumn{3}{|c|}{ United States } & \multicolumn{2}{|c|}{ United Kingdom } & \multicolumn{3}{|c|}{ Canada } & \multirow{2}{*}{$\begin{array}{c}\text { Japan } \\
\text { Model } \\
\text { (B) }\end{array}$} & \multirow{2}{*}{$\begin{array}{c}\text { France } \\
\text { Model } \\
\text { (B) }\end{array}$} & \multirow{2}{*}{$\begin{array}{l}\text { Australia } \\
\text { Model } \\
\text { (A) }\end{array}$} \\
\hline & $\begin{array}{l}\text { Model } \\
\text { (A) }\end{array}$ & $\begin{array}{l}\text { Model } \\
\text { (C) }\end{array}$ & $\begin{array}{l}\text { Model } \\
\text { (D) }\end{array}$ & $\begin{array}{l}\text { Model } \\
\text { (A) }\end{array}$ & $\begin{array}{l}\text { Model } \\
\text { (C) }\end{array}$ & $\begin{array}{l}\text { Model } \\
\text { (A) }\end{array}$ & $\begin{array}{l}\text { Model } \\
\text { (C) }\end{array}$ & $\begin{array}{l}\text { Model } \\
\text { (D) }\end{array}$ & & & \\
\hline sample period & $\begin{array}{l}\text { 1960:Q1- } \\
\text { 2000:Q4 }\end{array}$ & $\begin{array}{l}\text { 1960:Q1- } \\
\text { 2000:Q4 }\end{array}$ & $\begin{array}{l}\text { 1960:Q1- } \\
\text { 2000:Q4 }\end{array}$ & $\begin{array}{l}\text { 1970:Q1- } \\
\text { 2000:Q3 }\end{array}$ & $\begin{array}{l}\text { 1970:Q1- } \\
\text { 2000:Q3 }\end{array}$ & $\begin{array}{l}\text { 1976:Q1- } \\
\text { 2000:Q4 }\end{array}$ & $\begin{array}{l}\text { 1976:Q1- } \\
\text { 2000:Q4 }\end{array}$ & $\begin{array}{l}\text { 1976:Q1- } \\
\text { 2000:Q4 }\end{array}$ & $\begin{array}{l}\text { 1980:Q2- } \\
\text { 2000:Q4 }\end{array}$ & $\begin{array}{l}\text { 1978:Q1- } \\
\text { 1998:Q4 }\end{array}$ & $\begin{array}{l}\text { 1981:Q1- } \\
\text { 1999:Q2 }\end{array}$ \\
\hline $\begin{array}{l}\text { 1. Estimated long- } \\
\text { run elasticity with } \\
\text { respect to wealth }\end{array}$ & .289 & .230 & .099 & .195 & .088 & .407 & .32 & .139 & .285 & .101 & .219 \\
\hline $\begin{array}{l}\text { 2. Average W/C } \\
1995-1998\end{array}$ & 5.3 & 3.9 & 1.6 & 4.5 & 2.1 & 4.9 & 3.3 & 1.6 & 2.7 & 3.7 & 4.5 \\
\hline $\begin{array}{l}\text { 3. mpc out of } \\
\text { wealth = line (1) / } \\
\text { line (2) }\end{array}$ & .054 & .059 & .062 & .043 & .042 & .083 & .097 & .087 & .106 & .027 & .049 \\
\hline 4. $\mathrm{W} / \mathrm{C}$ in 1998 & 6.1 & 5.0 & 3.0 & 6.3 & 3.6 & 5.3 & 3.8 & 2.4 & 2.8 & 6.0 & 5.4 \\
\hline $\begin{array}{l}\text { 5. Equity share in } \\
1998\end{array}$ & .37 & .45 & .78 & .30 & .52 & .36 & .51 & .78 & .16 & .16 & .17 \\
\hline $\begin{array}{l}\text { 6. } \% \text { increase in } \\
\text { wealth from } 10 \% \\
\text { increase in stock } \\
\text { prices = line (5) } x \\
0.1\end{array}$ & 3.7 & 4.5 & 7.8 & 3.0 & 5.2 & 3.6 & 5.1 & 7.8 & 1.6 & 1.6 & 1.7 \\
\hline $\begin{array}{l}\text { 7. Estimated \% } \\
\text { increase in } \\
\text { consumption }\end{array}$ & 1.2 & 1.3 & 1.4 & .8 & .8 & 1.6 & 1.8 & 1.7 & .5 & .3 & .5 \\
\hline
\end{tabular}




\begin{tabular}{|c|c|c|c|c|c|c|c|c|}
\hline \multicolumn{9}{|c|}{$\begin{array}{l}\text { Table } 7 . \\
\text { Estimated long-run consumption response to permanent } 10 \text { percent increase in housing prices, } \\
\text { Using estimated LR coefficients on log level non-financial wealth from ECM stage } 1 \text { regressions }\end{array}$} \\
\hline & \multicolumn{3}{|c|}{ United States } & \multicolumn{2}{|c|}{ United Kingdom } & \multicolumn{2}{|c|}{ Canada } & \multirow{2}{*}{$\begin{array}{l}\text { Australia } \\
\text { Model } \\
\text { (A) }\end{array}$} \\
\hline & $\begin{array}{l}\text { Model } \\
\text { (A) }\end{array}$ & $\begin{array}{l}\text { Model } \\
\text { (C) }\end{array}$ & $\begin{array}{l}\text { Model } \\
\text { (D) }\end{array}$ & $\begin{array}{l}\text { Model } \\
\text { (A) }\end{array}$ & $\begin{array}{l}\text { Model } \\
\text { (C) }\end{array}$ & $\begin{array}{l}\text { Model } \\
\text { (A) }\end{array}$ & $\begin{array}{l}\text { Model } \\
\text { (D) }\end{array}$ & \\
\hline sample period & $\begin{array}{l}\text { 1960:Q1- } \\
\text { 2000:Q4 }\end{array}$ & $\begin{array}{l}\text { 1960:Q1- } \\
\text { 2000:Q4 }\end{array}$ & $\begin{array}{l}\text { 1960:Q1- } \\
\text { 2000:Q4 }\end{array}$ & $\begin{array}{l}\text { 1970:Q1- } \\
\text { 2000:Q3 }\end{array}$ & $\begin{array}{l}\text { 1970:Q1- } \\
\text { 2000:Q3 }\end{array}$ & $\begin{array}{l}\text { 1976:Q1- } \\
\text { 2000:Q4 }\end{array}$ & $\begin{array}{l}\text { 1976:Q1- } \\
\text { 2000:Q4 }\end{array}$ & $\begin{array}{l}\text { 1981:Q1- } \\
\text { 1999:Q2 }\end{array}$ \\
\hline $\begin{array}{l}\text { 1. Estimated long-run } \\
\text { elasticity with respect to } \\
\text { wealth }\end{array}$ & .289 & .136 & .281 & .195 & .092 & .407 & .155 & .219 \\
\hline $\begin{array}{l}\text { 2. Average W/C } \\
\text { 1995-1999 }\end{array}$ & 5.3 & 1.4 & 3.7 & 4.5 & 2.1 & 4.9 & 1.6 & 4.5 \\
\hline $\begin{array}{l}\text { 3. mpc out of wealth } \\
=\text { line (1) / line (2) }\end{array}$ & .054 & .097 & .076 & .043 & .042 & .083 & .087 & .049 \\
\hline 4. $\mathrm{W} / \mathrm{C}$ in 1998 & 6.1 & 1.1 & 3.1 & 6.3 & 2.7 & 5.3 & 3.3 & 5.4 \\
\hline 5. Housing share in 1998 & .20 & .94 & .43 & .43 & 1.00 & .25 & .47 & .60 \\
\hline $\begin{array}{l}\text { 6. \% increase in wealth from } \\
10 \% \text { increase in house prices } \\
=\text { line }(5) \times 0.1\end{array}$ & 2.2 & 9.4 & 4.3 & 4.3 & 10.0 & 2.5 & 4.7 & 6.0 \\
\hline $\begin{array}{l}\text { 7. Estimated } \% \text { increase in } \\
\text { consumption } \\
=\text { line }(3) \times \text { line }(4) \times \text { line }(6)\end{array}$ & 0.7 & 1.0 & 1.0 & 1.2 & 1.0 & 1.1 & 1.3 & 1.6 \\
\hline
\end{tabular}




\begin{tabular}{|c|c|c|c|c|c|c|c|c|c|c|c|}
\hline & \multicolumn{3}{|c|}{ United States } & \multicolumn{2}{|c|}{ United Kingdom } & \multicolumn{3}{|c|}{ Canada } & \multirow{2}{*}{$\begin{array}{c}\text { Japan } \\
\text { Model } \\
\text { (B) }\end{array}$} & \multirow{2}{*}{$\begin{array}{c}\text { France } \\
\text { Model } \\
\text { (B) }\end{array}$} & \multirow{2}{*}{$\begin{array}{c}\text { Australia } \\
\text { Model } \\
\text { (A) }\end{array}$} \\
\hline & $\begin{array}{l}\text { Model } \\
\text { (A) }\end{array}$ & $\begin{array}{l}\text { Model } \\
\text { (C) }\end{array}$ & $\begin{array}{l}\text { Model } \\
\text { (D) }\end{array}$ & $\begin{array}{l}\text { Model } \\
\text { (A) }\end{array}$ & $\begin{array}{l}\text { Model } \\
\text { (C) }\end{array}$ & $\begin{array}{l}\text { Model } \\
\text { (A) }\end{array}$ & $\begin{array}{l}\text { Model } \\
\text { (C) }\end{array}$ & $\begin{array}{l}\text { Model } \\
\text { (D) }\end{array}$ & & & \\
\hline sample period & $\begin{array}{l}1980: 1- \\
2000: 4\end{array}$ & $\begin{array}{l}1980: 1- \\
2000: 4\end{array}$ & $\begin{array}{l}1980: 1- \\
2000: 4\end{array}$ & $\begin{array}{l}\text { 1980:1- } \\
2000: 3\end{array}$ & $\begin{array}{l}1980: 1- \\
2000: 3\end{array}$ & $\begin{array}{l}1980: 2- \\
2000: 4\end{array}$ & $\begin{array}{l}1980: 2- \\
2000: 4\end{array}$ & $\begin{array}{l}1980: 2- \\
2000: 4\end{array}$ & $\begin{array}{l}1980: 2- \\
1998: 4\end{array}$ & $\begin{array}{l}1980: 2- \\
1998: 4\end{array}$ & $\begin{array}{l}1980: 2- \\
1998: 4\end{array}$ \\
\hline $\begin{array}{l}\text { residual from stage } 1 \\
\text { levels regression }\end{array}$ & $-.110^{*}$ & $-.166^{* *}$ & $-.115+$ & $-.301 * *$ & $-.278 * *$ & $-.107+$ & $-.358 * *$ & $-.247 * *$ & $-.159 *$ & -.045 & $-.231 * *$ \\
\hline Sum $\Delta \log$ consumption & $.395^{* *}$ & .380 & $.602 * *$ & $.637 * *$ & $.794 * *$ & $.637 * *$ & $.796 * *$ & $1.028^{* *}$ & -.340 & $.010+$ & $.490 *$ \\
\hline Sum $\triangle \log$ income & .179 & .047 & .264 & $-.265^{* *}$ & $-.391 * *$ & $-.372 * *$ & $-.387 * *$ & $-.530 * *$ & -.050 & .207 & $-.391+$ \\
\hline Sum $\Delta \log$ total wealth & $.127^{*}$ & & & & & & & & & & --- \\
\hline $\operatorname{Sum} \Delta \log$ fin. wealth & & $.105 * *$ & & .014 & .015 & $.605 * *$ & $.463 * *$ & . & .053 & $.021^{*}$ & \\
\hline Sum $\Delta \log$ nonfin. wealth & & .067 & & $.088^{*}$ & --- & $.082+$ & $.093^{*}$ & & & & \\
\hline Sum $\Delta \log$ equity wealth & & & $.065^{* *}$ & & & & & $160+$ & & & \\
\hline Sum $\Delta \log$ noneq. wealth & & & $-.023+$ & & & & & $.140^{*}$ & & & \\
\hline$\Delta$ unemployment rate & --- & -.003 & $.005+$ & $-.006^{*}$ & $-.006^{*}$ & --- & --- & --- & $-.005^{1}$ & --- & $-.009 * *$ \\
\hline$\Delta$ real interest rate & -.001 & $-.001 *$ & --- & --- & -.001 & $-.002 * *$ & $-.002 * *$ & $-.002 * *$ & --- & --- & --- \\
\hline constant & $.003^{*}$ & $.003^{*}$ & .001 & $.003+$ & .003 & -.002 & -.001 & -.000 & $.030 * *$ & $.003 * *$ & $.007 * *$ \\
\hline Sum $\Delta \log$ property price & & & & & & & & & $.069 * *$ & & \\
\hline Dummy variables: & 1980Q2 & 1980Q2 & 1980Q2 & & & 1991Q1 & 1991Q1 & 1991Q1 & $\begin{array}{l}\text { 1990Q1 } \\
\text { 1997Q1 } \\
\text { 1997Q2 }\end{array}$ & $\begin{array}{l}\text { 1993Q1 } \\
\text { 1996Q1 } \\
\text { 1996Q4 }\end{array}$ & $1980 \mathrm{Q} 4$ \\
\hline $\mathrm{R}^{2}$ & .554 & .575 & .610 & .514 & .511 & .60 & .673 & .540 & .640 & .493 & .406 \\
\hline
\end{tabular}




\section{Figure 1}

Equity Prices, 1995-2001

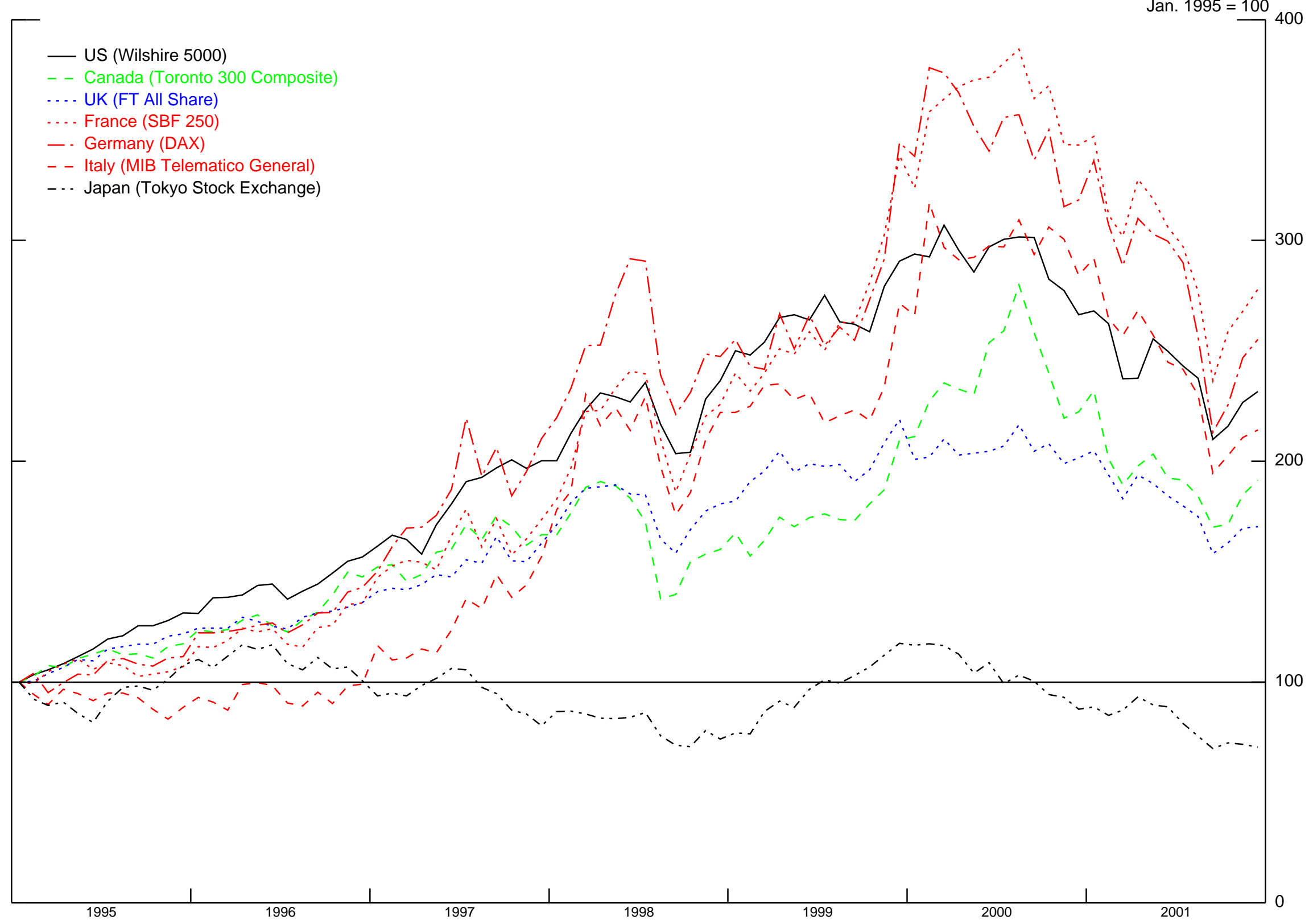




\section{Figure 2}

United States

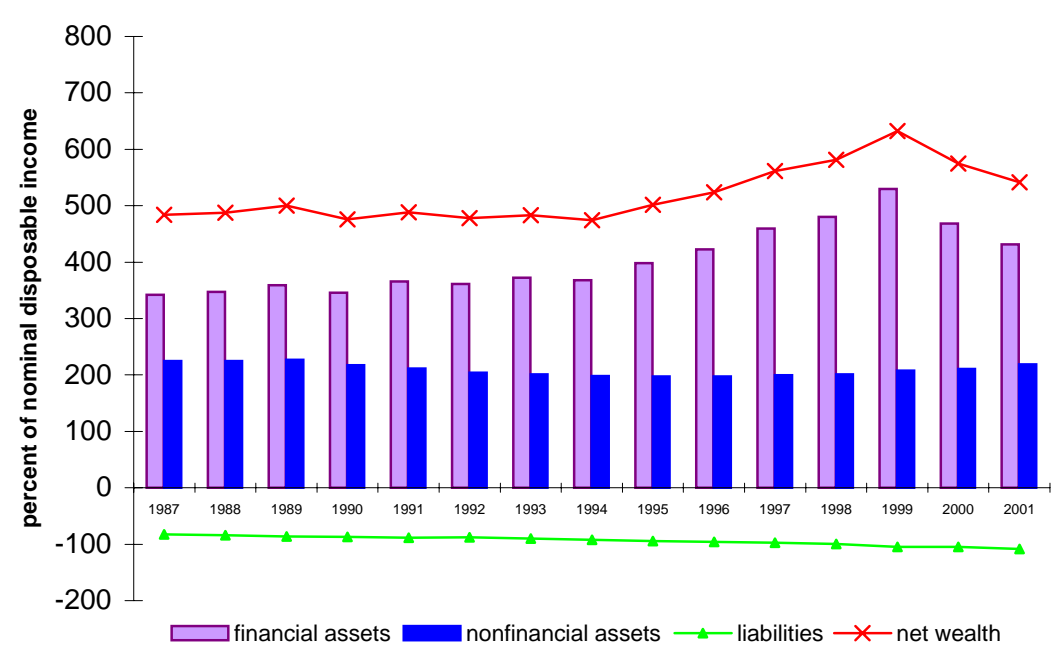

United Kingdom

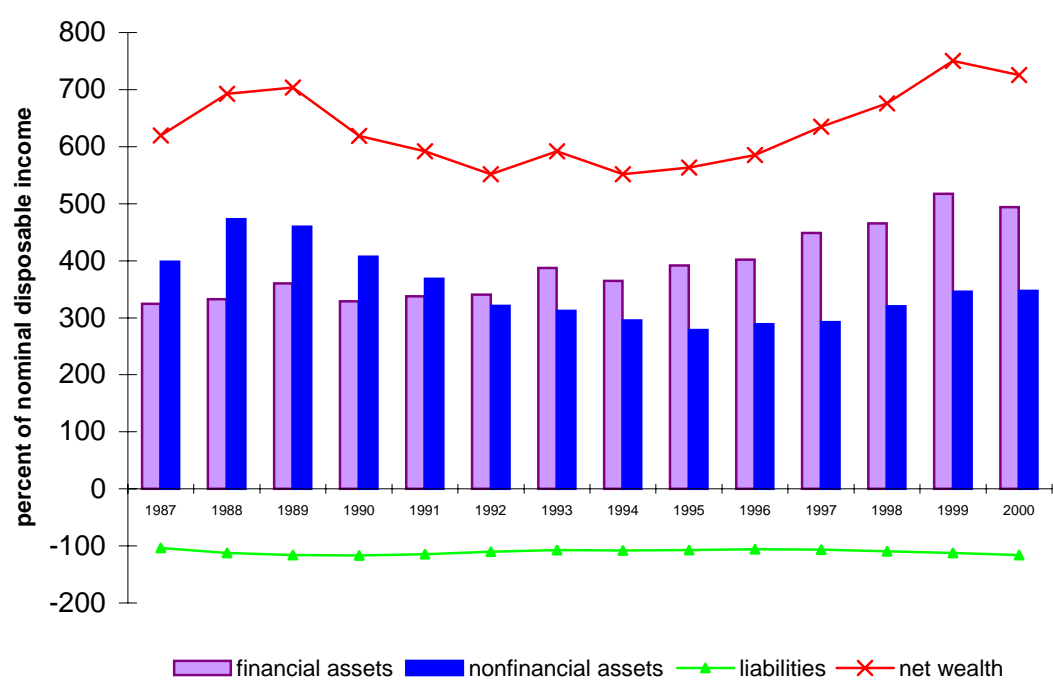

Canada

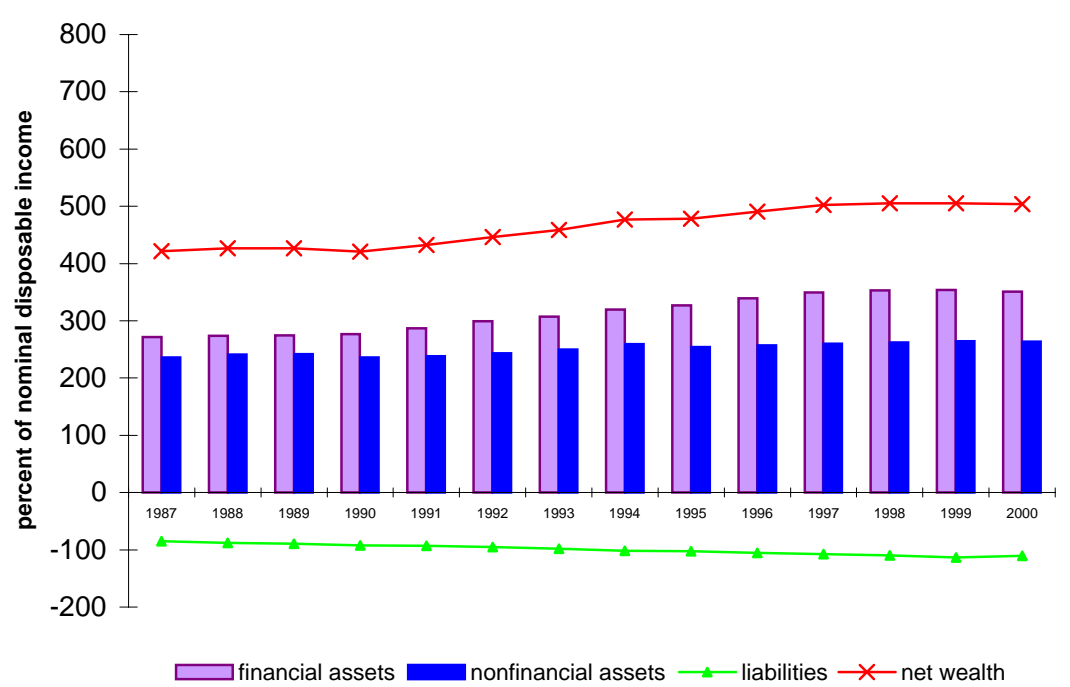

Japan

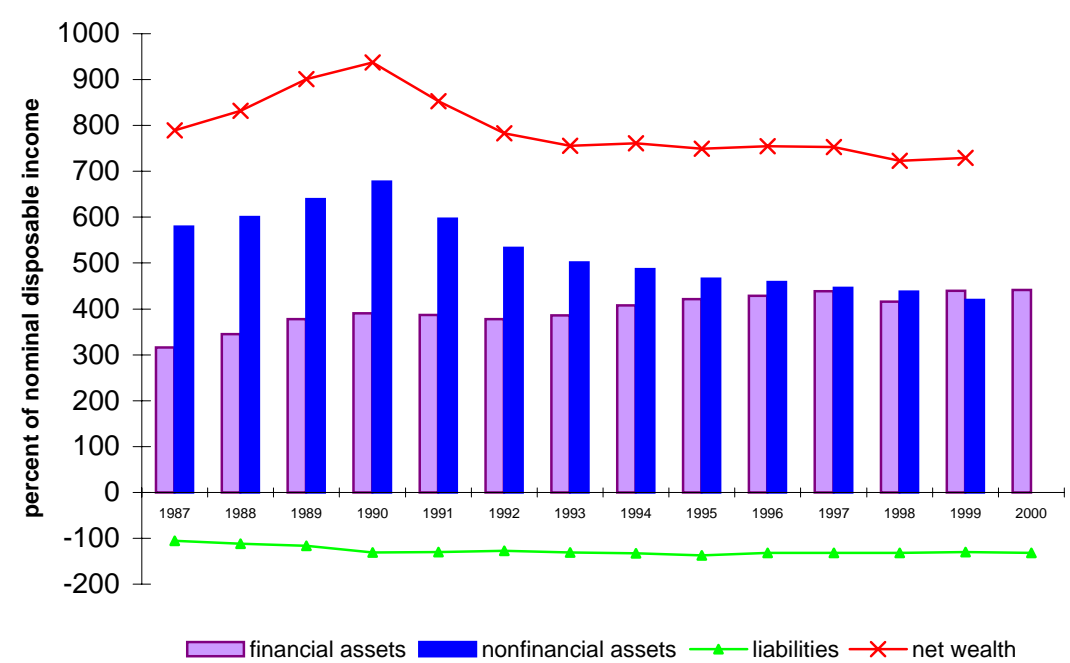


Figure 3

France

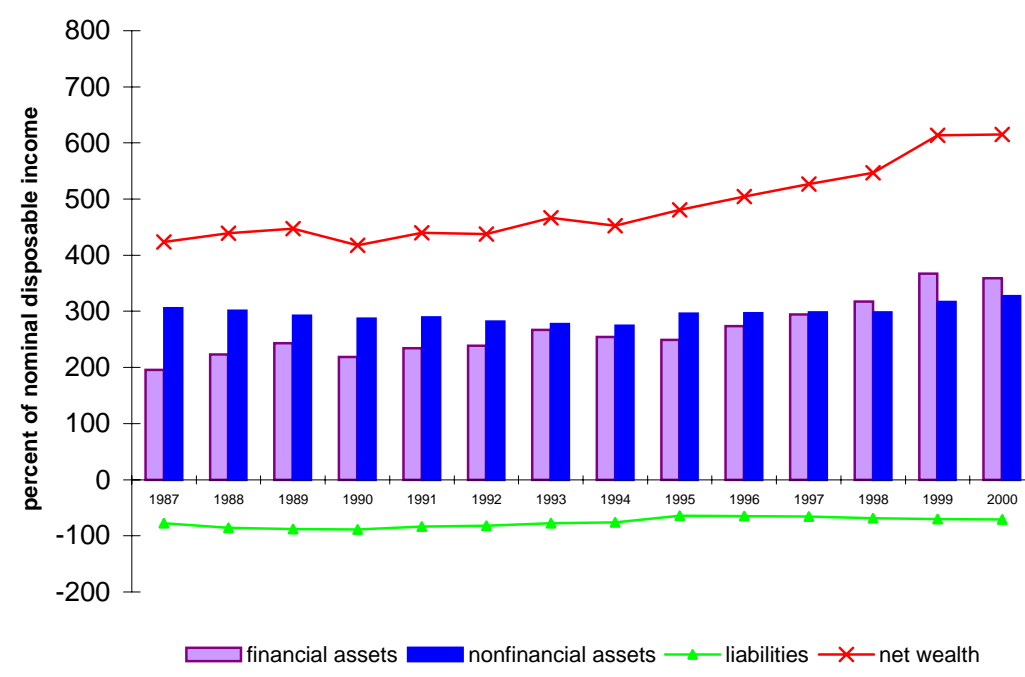

Italy

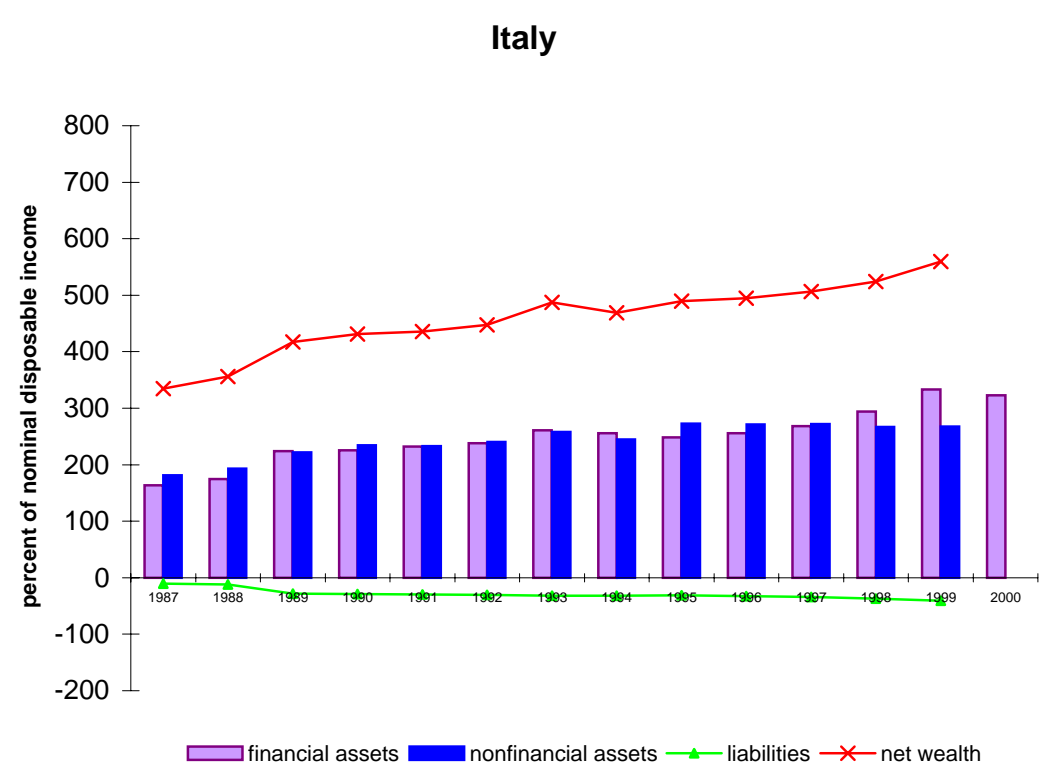

Germany

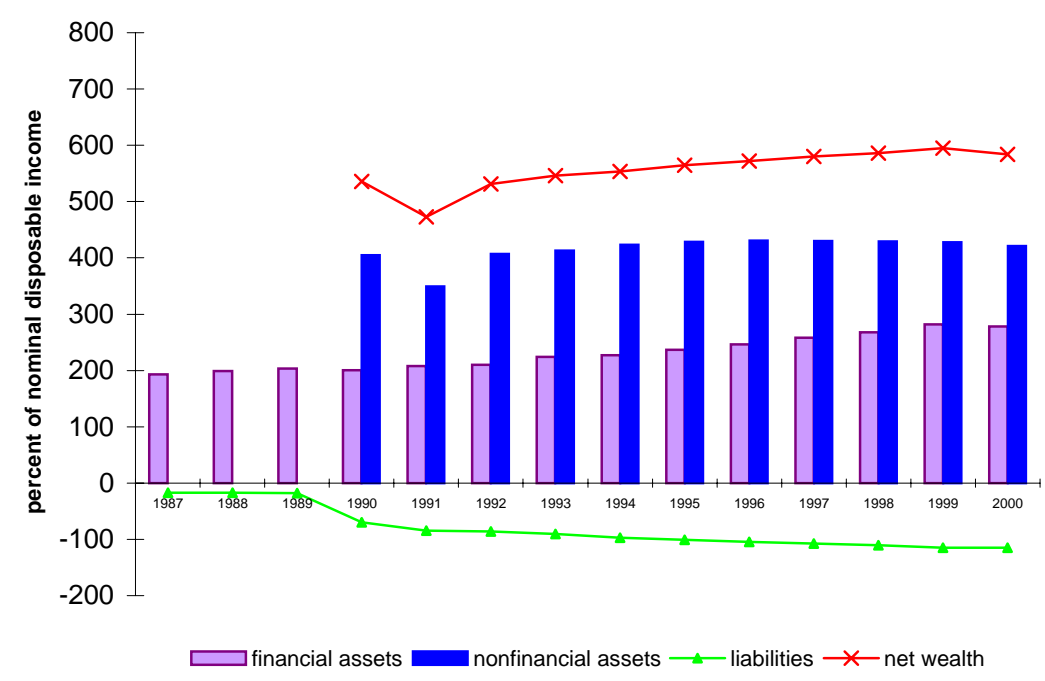


Figure 4

Financial Assets as a Percentage of Household Disposable Income, 1990-2000

United States

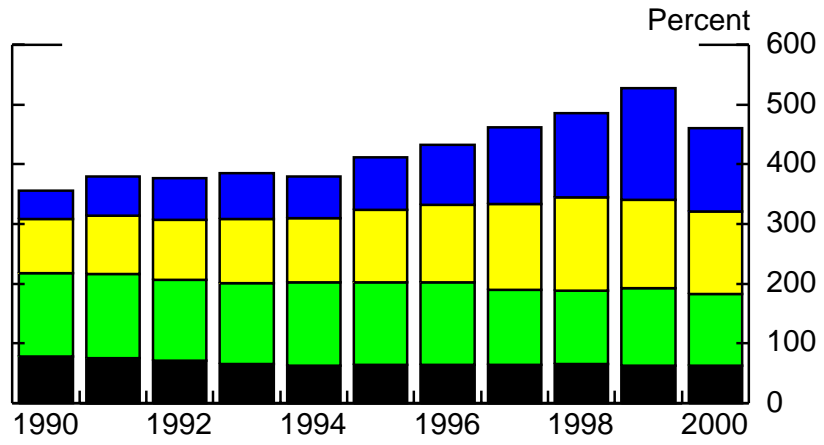

Canada

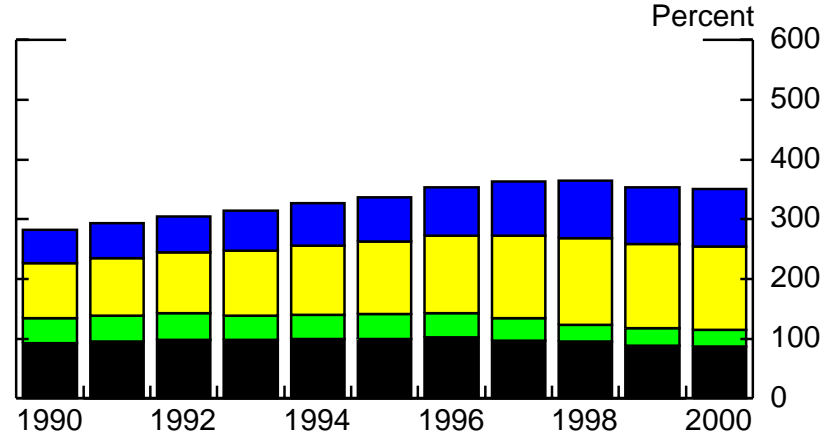

United Kingdom

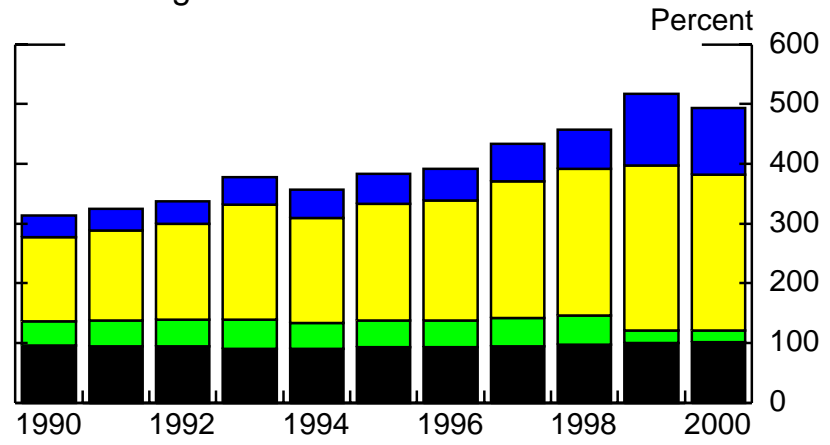

France

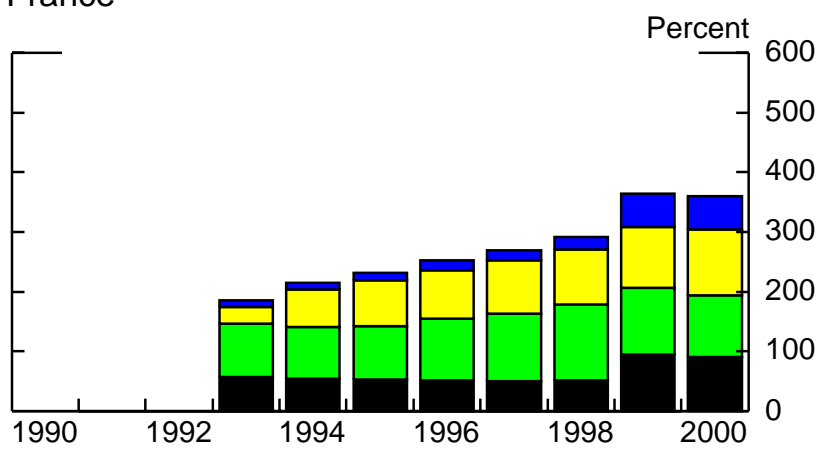

Germany

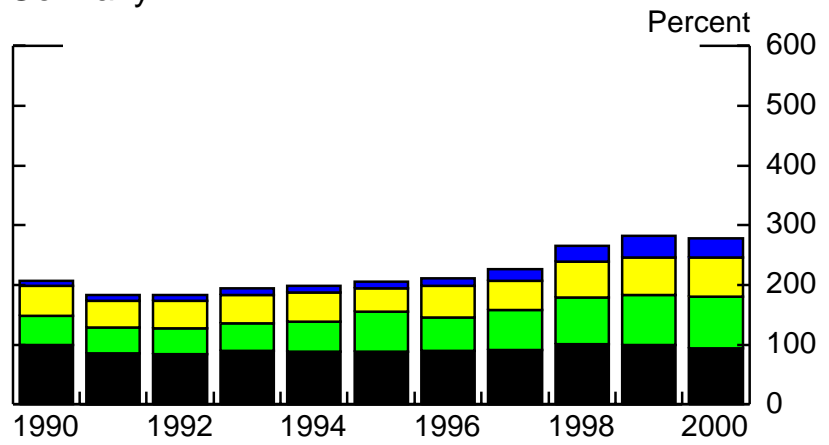

Italy

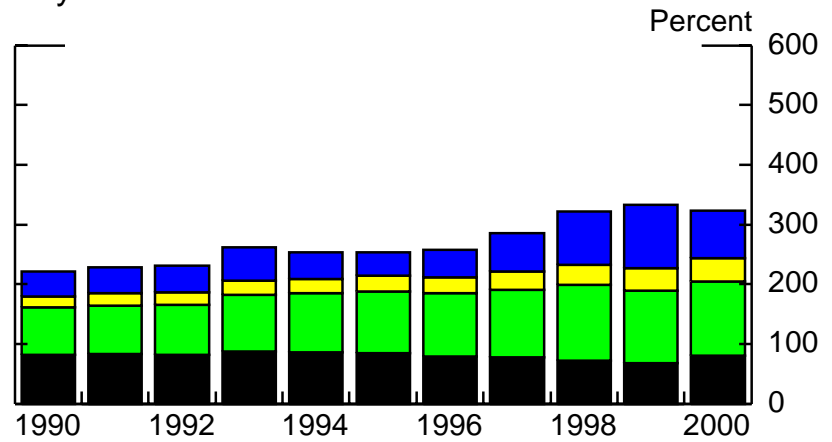

Japan

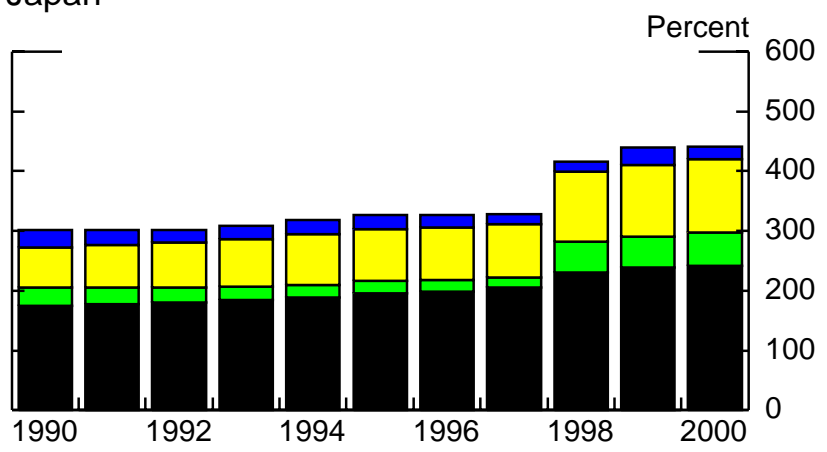


35

Figure 5

A. US consumption growth actual vs model estimates

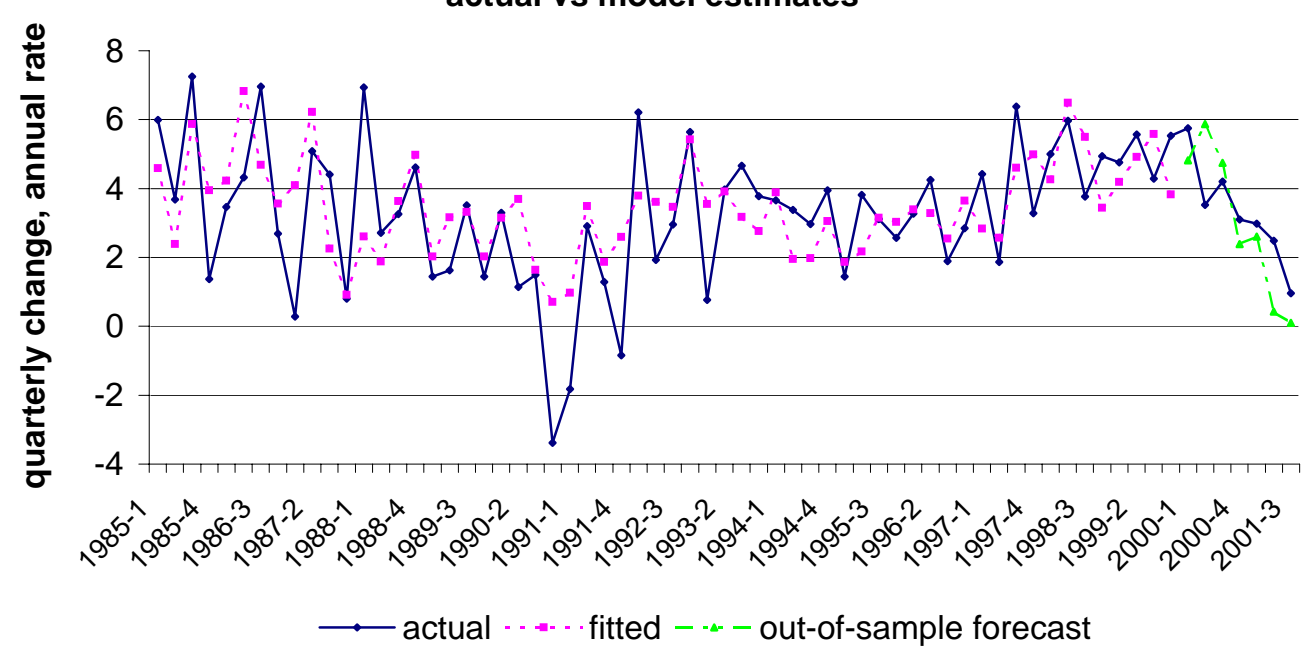

B. Canadian consumption growth actual vs model estimates

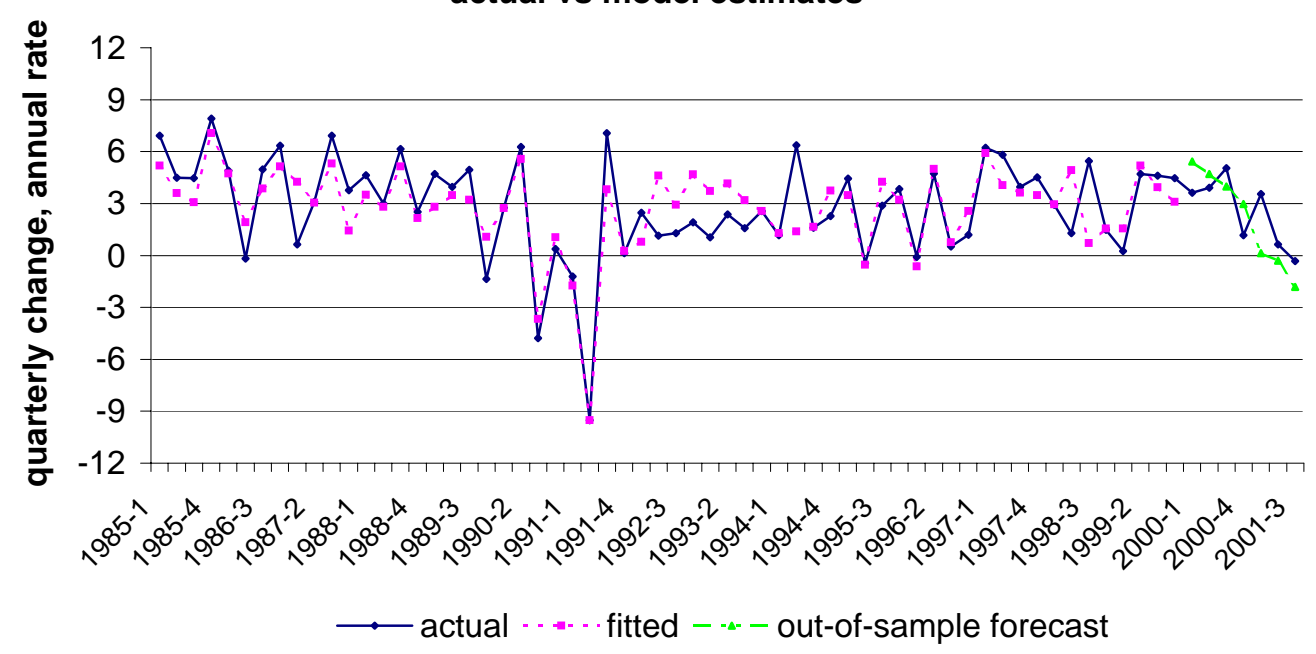

C. UK consumption growth actual vs model estimates

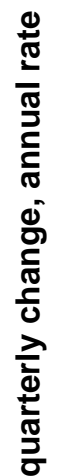

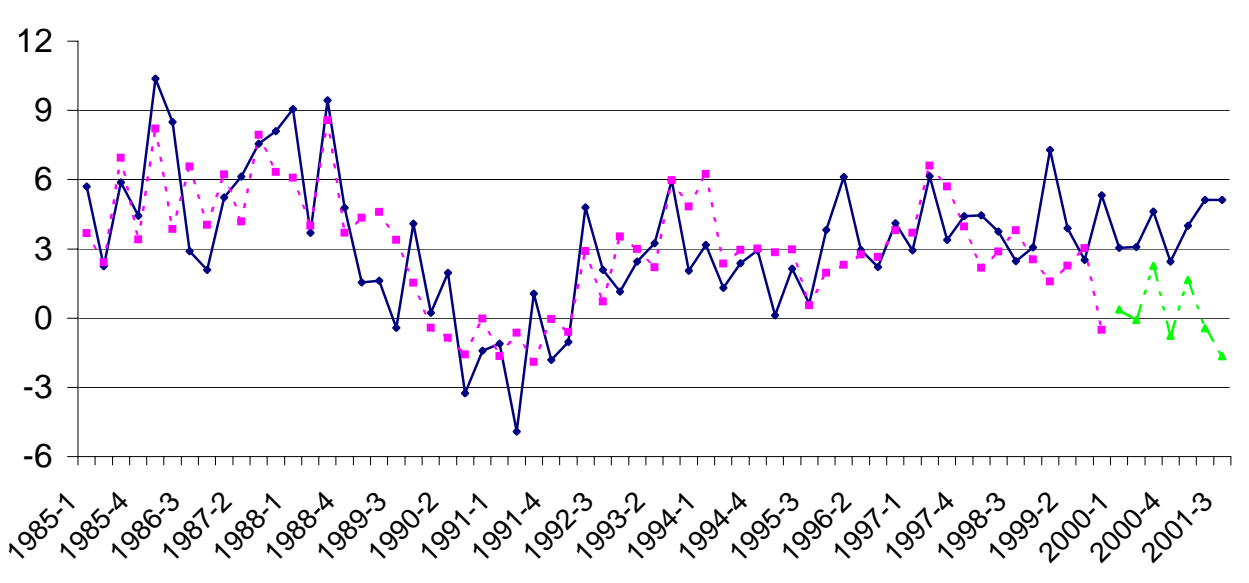

- actual -..- fitted - - - out-of-sample forecast 


\section{Appendix I: Unit root tests and tests of cointegration}

\section{Augmented Dickey-Fuller tests for Unit Roots in log consumption, log income, and log wealth} A significant test result rejects null of a unit root.

\begin{tabular}{|c|c|c|c|c|c|c|c|}
\hline \multicolumn{8}{|c|}{$\begin{array}{l}\text { Table A1. } \\
\text { Augmented Dickey-Fuller t-statistics for log-levels of consumption, income, and wealth. } \\
\text { Model includes a constant and time trend }\end{array}$} \\
\hline & \multicolumn{2}{|c|}{ United States } & United & Canada & Japan & France & Australia \\
\hline \multicolumn{8}{|l|}{ L consumption } \\
\hline 4 & -3.146 & & -2.113 & -2.729 & -.356 & -1.694 & -2.853 \\
\hline 3 & -3.237 & & -2.122 & -2.845 & -.145 & -1.612 & -2.788 \\
\hline 2 & -2.846 & & -1.900 & -.2129 & .258 & -1.458 & -2.526 \\
\hline 1 & -2.672 & & -1.361 & -1.680 & .374 & -1.484 & -2.602 \\
\hline 0 & -2.663 & & -.860 & -1.626 & -.418 & -1.648 & -2.602 \\
\hline \multicolumn{8}{|l|}{ L income } \\
\hline 4 & -2.611 & & -1.809 & -2.171 & .576 & -3.342 & -3.574 \\
\hline 3 & -2.586 & & -1.679 & -2.035 & .887 & -3.113 & -3.243 \\
\hline 2 & -2.543 & & -1.916 & -1.919 & .507 & -2.411 & -3.301 \\
\hline 1 & -2.551 & & -1.728 & -1.941 & -.261 & -2.294 & -3.298 \\
\hline 0 & -2.556 & & -2.068 & -2.225 & -2.632 & -2.616 & -3.879 \\
\hline $\mathrm{L}$ financial wealth & & \multicolumn{5}{|c|}{ L equity wealth } & $\begin{array}{l}\mathrm{L} \text { total } \\
\text { wealth }\end{array}$ \\
\hline 4 & -.600 & -.387 & -1.902 & -2.688 & -.342 & -2.518 & -1.277 \\
\hline 3 & -.678 & -.437 & -2.706 & -2.732 & .260 & -3.097 & -.461 \\
\hline 2 & -.579 & -.435 & -2.079 & -2.761 & .179 & -3.117 & -.982 \\
\hline 1 & -.856 & -.645 & -2.748 & -2.702 & .457 & -3.276 & .287 \\
\hline 0 & -.720 & -.526 & -2.956 & -2.645 & .011 & -2.831 & .993 \\
\hline $\begin{array}{l}\text { L non-financial } \\
\text { wealth }\end{array}$ & & \multicolumn{5}{|c|}{ L non-equity wealth } & \\
\hline 4 & -2.183 & -2.063 & & -3.483 & -1.385 & & \\
\hline 3 & -1.868 & -1.890 & & -2.447 & -.898 & & \\
\hline 2 & -1.812 & -1.526 & & -2.273 & -2.637 & & \\
\hline 1 & -1.282 & -1.309 & & -1.775 & -.839 & & \\
\hline 0 & -.756 & -.792 & & -1.322 & 1.375 & & \\
\hline
\end{tabular}


In almost all cases, the Dickey-Fuller t-statistics are unable to reject the null of a unit root at the 5 percent confidence interval. In the few cases where the t-statistic is larger than the $5 \%$ critical value, the value is close. Thus, a working assumption is that the variables are $\mathrm{I}(1)$.

\section{Cointegration test results:}

I tested for significant cointegrating vectors using the Johansen procedure. For cases where both financial and nonfinancial wealth are available, the test is for rank $p=0$ up to $p<=3$. For cases where there is only one measure of wealth, the test is for rank $\mathrm{p}=0$ up to $\mathrm{p}<=2$. Overall, the results suggest that there is at least one, and most commonly, only one, cointegrating vector between the log-levels of consumption, income, and wealth in all the countries considered except France.

Table A2 below reports the results for a VAR with 2 lags, except for Japan, where the model shown has three lags. Tests were also performed on models with 1,3, and 4 lags; in most cases, the results were little changed to additional or fewer lags in the model; an exception is Japan where the results for lags $=3$ and lags $=1$ were more similar than for lags $=2$. . The model shown includes a linear trend and a constant, which were not restricted to enter the cointegrating relationship. In most cases, however, the results were not affected by removing the trend term.

For Canada, the results shown suggest there could be two cointegrating vectors. However, this conclusion is less clear-cut if ether 1 or 3 lags are included, and if the time trend is excluded.

For France, the results suggest little evidence of a significant cointegrating relationship. This result was not dependent on the number of lags included, or the inclusion of the time trend. 
Table A2. Results for cointegration tests, Lags in VAR model=2. Model includes unrestricted constant $\&$ time trend.

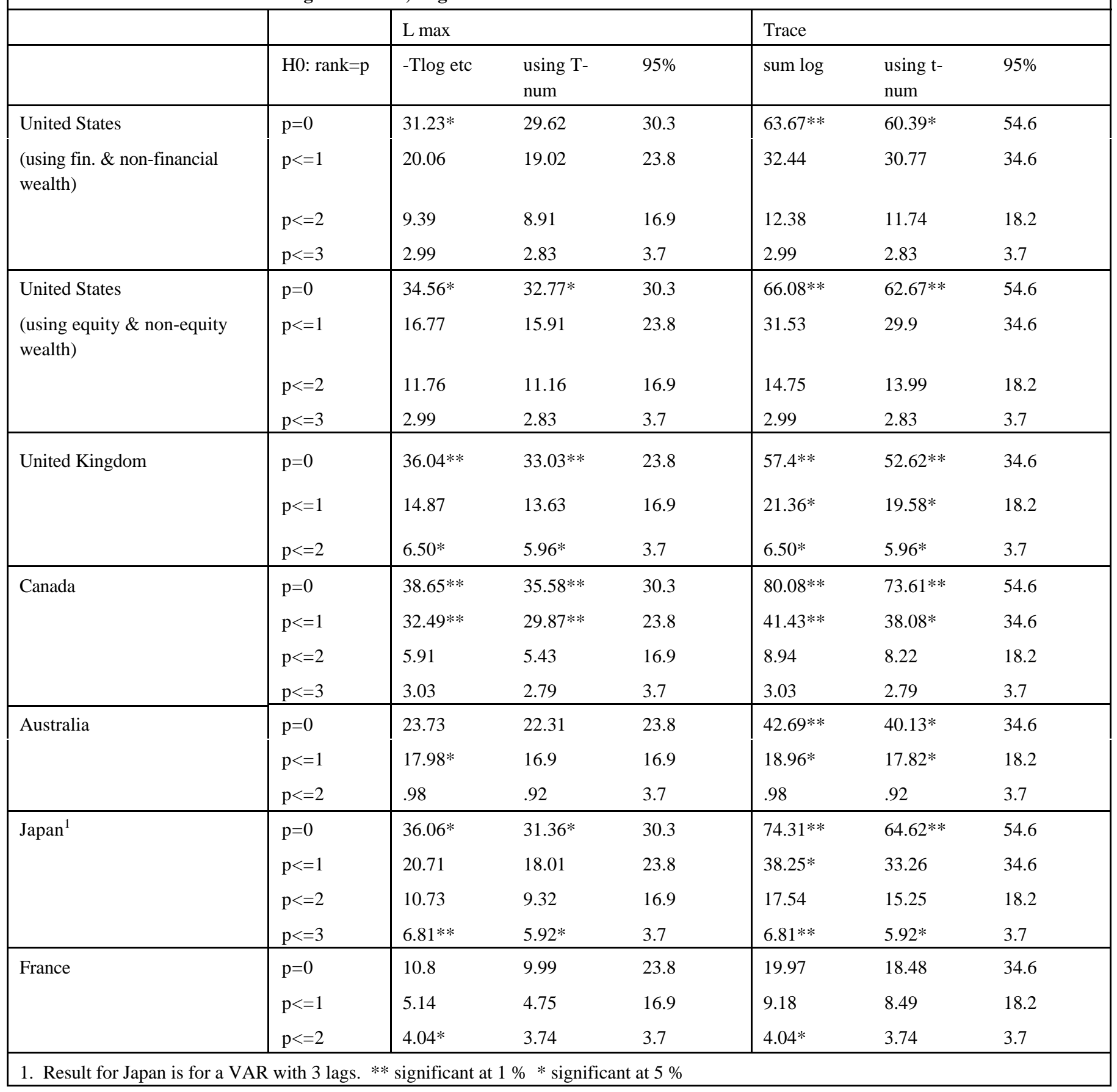




\section{Appendix II: Details of the Error-Correction Estimation}

1. Long-run levels regressions

Estimates of the long-run relationship between consumption, income, and wealth use the Stock and Watson (1993) dynamic OLS approach, which includes leads and lags of changes in the right-hand side variables to reduce the effects of regressor endogeneity.

The standard regression equation (Model A) is of the form

$$
l c_{t}=\alpha_{0}+\beta_{1} l y_{t}+\beta_{2} l w_{t}+\sum_{i=1}^{2} \delta_{i j} d l y_{t-i}+\sum_{i=1}^{2} \delta_{2 i} d l w_{t-i}+\varepsilon_{t}
$$

where $\mathrm{lc}$ is the log level of real consumption

ly is the log level of real disposable income, and

$\mathrm{lw}$ is the log level of real wealth.

This equation was estimated for countries where an aggregate measure of wealth is available (the United States, Canada, the United Kingdom, and Australia).

For France and Japan, the specification is the same but the measure of wealth includes only financial wealth (Model B).

For the United States, the United Kingdom, and Canada, Model C has the same basic form but includes both financial and nonfinancial wealth, entered separately:

$$
l c_{t}=\alpha_{0}+\beta_{1} l y_{t}+\beta_{2} l f w_{t}+\beta_{3} l n f w_{t} \sum_{i=1}^{2} \delta_{{ }_{1 i}} d l y_{t-i}+\sum_{i=1}^{2} \delta_{2 i} d l f w_{t-i}+\sum_{i=1}^{2} \delta_{{ }_{3}} d \ln f w_{t-i}+\varepsilon_{t}
$$

For the United States and Canada, an additional set of estimates were run where wealth was separated into equity wealth and total non-equity wealth (Model D). For Canada, estimates of quarterly wealth levels were constructed from year-end balance sheet data and quarterly flows. In all cases, nominal wealth data were deflated using the relevant country consumption deflator.

For all countries, the equations were estimated using quarterly data. For the United States, the regressions were estimated over the period 1960:4 to 2000:4; for the United Kingdom, 1970Q1:2000Q3; for Canada, 1976Q1:2000Q4; for Japan, 1980Q2:2000Q4; for France, 1978Q1:1998Q4; and for Australia, 1981Q1:1999Q2. 
2. Second-stage consumption growth equations

The standard regression equation was of the form

where dlc is the change in log consumption,

dly is the change in real personal disposable income,

dlwealth is the change in the log value of the relevant real wealth variable;

$\mathrm{dr}$ is the change in a three-month market interest rate minus 4-quarter inflation as measured by the GDP deflator,

dur is the change in the unemployment rate, and

$E C M$ is the residual from the first-stage levels regression.

$$
\begin{aligned}
& d l c_{t}=\alpha_{0}+\sum_{i=1}^{4} \alpha_{{ }_{1 i}} d l_{c_{t-i}}+\sum_{i=1}^{4} \alpha_{{ }_{2 i}} \text { dly }_{t-i}+\sum_{i=1}^{2} \alpha_{3 i} \text { dlwealth }_{t-i}+ \\
& \sum_{i=1}^{2} \alpha_{{ }_{4 i}} d r_{t-i}+\sum_{i=1}^{2} \alpha_{{ }_{5 i}} d U R_{t-i}+\alpha_{6} E C M+\varepsilon_{t}
\end{aligned}
$$

For models with both financial and non-financial wealth or equity and non-equity wealth, the model included terms

$$
\sum_{i=1}^{2} \alpha_{3 a i} d \text { l financial wealth } \text { fi-i }+\sum_{i=1}^{2} \alpha_{3 b i} \text { dl nonfinancial wealth } h_{t-i}
$$

Dummy variables were included for a large outlier in 1980-Q2 in several countries, for the break in series in 1991-Q1 resulting from German unification, and for the imposition of the consumption tax in Japan in 1997Q1. 


\section{Data sources for regression estimates:}

\section{Consumption:}

for all countries, total personal consumption expenditures from individual country national accounts

\section{Income:}

for all countries, income variables were taken from national accounts.

United States: non-capital personal disposable income.

Canada: wage and salary income.

United Kingdom: personal disposable income.

Australia: personal disposable income.

Japan: compensation of employees.

France: personal disposable income.

For countries where only nominal income was available, real disposable income was estimated by deflating nominal income by the consumption deflator.

\section{Quarterly household sector wealth estimates:}

\section{United States: Flow of Funds Accounts, Federal Reserve Board of Governors}

United Kingdom: Bank of England calculations from Household Sector balance sheet accounts, Office for National Statistics

Canada: author's calculations from Statistics Canada Annual balance sheet data and quarterly flow of funds accounts

Japan: Bank of Japan, Flow of Funds accounts; old basis through 1997; new basis from 1997

France: Bank de France

Australia: Bank for International Settlements estimates of quarterly wealth, derived from balance sheet accounts, Australia Bureau of Statistics

Stock price data: MCSI stock price indexes

Interest rates: representative 3-month market interest rate; real rates constructed as nominal rate minus 12-month rate of consumer price inflation. 


\section{References}

Bank of England, Inflation Report November 2001.

Bank of England, Economic Models at the Bank of England, September 2000 Update.

Bank for International Settlements, Annual Report 2000, pp. 16-18.

Bertaut and Starr-McCluer (2000), "Household Portfolios in the United States," Federal Reserve Board Finance and Discussion Series working paper 2000-46.

Boone, Girouard, and Wanner (2001), "Financia Market Liberalization, Wealth, and Consumption" OECD working paper 308 (September 2001).

Boone, Giornio, and Richardson (1998), "Stock Market Fluctuations and Consumption Behavior: Some Recent Evidence" OECD working paper 208 (December 1998)

Brayton and Tinsley (1996), "A Guide to FRB/US: A Macroeconomic Model of the United States," Federal Reserve Board Finance and Discussion Series working paper 1966-42

Davis and Palumbo (2001), "A Primer on the Economics and Time Series Econometrics of Wealth Effects, " Federal Reserve Board Finance and Discussion Series working paper working paper 2001-09.

Dynan and Maki (2001). "Does Stock Market Wealth Matter for Consumption?," Federal Reserve Board Finance and Discussion Series working paper 2001-0?.

Edison and Sløk (2001), "Wealth Effects and the New Economy,” IMF Working Paper, May 2001.

Greenspan, A. (2000), Testimony Before the Committee on Banking and Financial Services, U.S. House of Representatives, February 17, 2000.

Guiso, L., M. Haliassos, and T. Jappelli (eds), Household Portfolios, MIT Press: 2001.

Goldman-Sachs (2001a), "No Wealth Effect in Euroland" European Daily Comment, April 6, 2001.

Goldman-Sachs (2001b), "Wealth Effect Still Weak in Euroland" European Weekly Analyst, June 8, 2001. 
Houizot, C., H. Baudchon, C. Mathieu, and F. Serranito (2000), "Plus-values, consommation et épargne: Une estimation de l'effet richesse aux États-Unis et au Royaume-Uni," Revue de l'OFCE no. 73, April 2000.

International Monetary Fund, World Economic Outlook 2000.

Ludvigson, S. and C. Steindel, "How Important is the Stock Market Effect on Consumption?" Federal Reserve Bank of New York Policy Review 5, mo. 2 (July): 29-52.

OECD Economic Outlook vol 69: June 2001.

Otoo, M. "Consumer Sentiment and the Stock market." Federal Reserve Board Finance and Discussion Series working paper 1999-06.

Poterba, J. (2000), "Stock Market Wealth and Consumption," Journal of Economic Perspectives, Vol. 14, Number 2, Spring 2000, pp 99-119.

Poterba and Samwick, (1995), "Stock Ownership Patterns, Stock market Fluctuations, and Consumption," Brookings Papers on Economic Activity, No. 2, pp. 295-372.

Reifschneider, Tetlow, and Williams (1999), “Aggregate Disturbances, Monetary Policy, and the Macroeconomy: The FRB/US Perspective," Federal Reserve Bulletin, Vol. 85, pp. 1-19.

Shirvani and Wilbratte (2000), "Does Consumption Respond More Strongly to Stock Market Declines than to Increases?" International Economic Journal, Vol. 14, Number 3, pp. 41-49.

Starr-McCluer, M. (200), "Stock Market Wealth and Consumption.” Mimeo, Federal Reserve Board, February 2000.

Stock and Watson (1993), "A Simple Estimator of Cointegrating Vectors in Higher Order Integrated Systems," Econometrica 61: 783-820. 